\title{
Generation of aggregation prone N- terminally truncated amyloid $\beta$ peptides by meprin $\beta$ depends on the sequence specificity at the cleavage site
}

\author{
Caroline Schönherr ${ }^{1 \dagger}$, Jessica Bien ${ }^{1 \dagger}$, Simone Isbert ${ }^{1}$, Rielana Wichert ${ }^{2}$, Johannes Prox ${ }^{2}$, Hermann Altmeppen $^{3}$, \\ Sathish Kumar ${ }^{4}$, Jochen Walter ${ }^{4}$, Stefan F. Lichtenthaler ${ }^{5,6}$, Sascha Weggen ${ }^{7}$, Markus Glatzel ${ }^{3}$, \\ Christoph Becker-Pauly ${ }^{2^{*}}$ and Claus U. Pietrzik ${ }^{1 *}$
}

\begin{abstract}
Background: The metalloprotease meprin $\beta$ cleaves the Alzheimer's Disease (AD) relevant amyloid precursor protein (APP) as a $\beta$-secretase reminiscent of BACE-1, however, predominantly generating $\mathrm{N}$-terminally truncated A $32-x$ variants.

Results: Herein, we observed increased endogenous sAPPa levels in the brains of meprin $\beta$ knock-out (ko) mice compared to wild-type controls. We further analyzed the cellular interaction of APP and meprin $\beta$ and found that cleavage of APP by meprin $\beta$ occurs prior to endocytosis. The N-terminally truncated A $32-40$ variant shows increased aggregation propensity compared to $A \beta 1-40$ and acts even as a seed for $A \beta 1-40$ aggregation. Additionally, we observed that different APP mutants affect the catalytic properties of meprin $\beta$ and that, interestingly, meprin $\beta$ is unable to generate $\mathrm{N}$-terminally truncated A $\beta$ peptides from Swedish mutant APP (APPswe).
\end{abstract}

Conclusion: Concluding, we propose that meprin $\beta$ may be involved in the generation of $\mathrm{N}$-terminally truncated $A \beta 2-$ $x$ peptides of APP, but acts independently from BACE-1.

Keywords: Alzheimer's Disease, Meprin $\beta$, Metalloprotease, Amyloid precursor protein, Amyloid $\beta, N$-terminal truncation, APP mutations, Protein-protein interaction, Cell surface protein

\section{Background}

One of the major hallmarks of Alzheimer's Disease (AD) is the accumulation of soluble and aggregated amyloid $\beta$ $(\mathrm{A} \beta)$ peptides in the brains of $\mathrm{AD}$ patients. $\mathrm{A} \beta$ peptides are generated from the amyloid precursor protein (APP) in the amyloidogenic pathway through two consecutive cleavage events. Most prominent, BACE-1 ( $\beta$-site APP cleaving enzyme 1 ) cleaves APP at the $\beta$-secretase cleavage site and generates the $\mathrm{N}$-terminus of $\mathrm{A} \beta$ (described in [1]). As an aspartyl protease, BACE-1 is responsible

\footnotetext{
* Correspondence: cbeckerpauly@biochem.uni-kiel.de; pietrzik@uni-mainz.de ${ }^{\dagger}$ Equal contributors

${ }^{2}$ Institute of Biochemistry, Unit for Degradomics of the Protease Web, Christian-Albrechts-University, Otto-Hahn-Platz 9, 24118 Kiel, Germany 'Institute of Pathobiochemistry, University Medical Center of the Johannes Gutenberg University of Mainz, Duesbergweg 6, 55128 Mainz, Germany

Full list of author information is available at the end of the article
}

for the majority of $A \beta$ peptides generated in the acidic environment of endosomes and lysosomes [2-5]. Second, the $\gamma$-secretase complex cleaves the remaining 99 amino acids long C-terminal fragment (CTF/C99) and releases the $\mathrm{C}$-terminus of $\mathrm{A} \beta$. As both secretases are not restricted to a single site, $A \beta$ peptides vary in length. BACE-1 can generate $A \beta$ starting in position $p 1$ or p11 (A $\beta 1-\mathrm{x} / 11-\mathrm{x})$ [3] whereas $\gamma$-secretase complex has several cleavage sites and can generate varying $C$ termini of $A \beta$ [6-10]. Based on genetic evidence and BACE-1 knock-out studies it has been demonstrated that BACE-1 is the quantitatively most important enzyme to generate $A \beta$ in mice overexpressing APP with the Swedish mutation (APPswe), which is associated with a distinct form of familial AD (FAD) [3, 11-15]. 
However, $\mathrm{N}$-terminally truncated $\mathrm{A} \beta$ variants starting with the alanine in $\mathrm{p} 2(\mathrm{~A} \beta 2-\mathrm{x})$, which cannot be attributed to BACE-1 activity, have also been described in AD patients [16-19]. We recently identified meprin $\beta$ as a new enzyme in APP processing as it is able to generate $\mathrm{A} \beta$ peptides starting with aspartate in $\mathrm{p} 1$ and with alanine in $\mathrm{p} 2$ independent of BACE-1 activity $[20,21]$. Meprin $\beta$, a type I transmembrane metalloprotease, has biological functions in inflammation and collagen assembly and is associated with diseases, such as inflammatory bowel disease and fibrosis (reviewed in $[22,23]$ ).

Although BACE- 1 acts as the major $\beta$-secretase in vivo generating most of the $A \beta$ peptides at position 1 , we suggest that meprin $\beta$ may act as an alternative enzyme responsible for the release of small amounts of $\mathrm{N}$ terminally truncated $\mathrm{A} \beta$ species.

The relevance of the protease for APP processing is further highlighted by its activity on endogenous APP in the mouse brain. Additionally we demonstrate that meprin $\beta$ cleavage of APP occurs prior to the endocytic compartments, as diminished APP endocytosis has no influence on meprin $\beta$ mediated $A \beta$ generation (summarized in Fig. 1). Moreover, we are able to demonstrate that meprin $\beta$ generates $\mathrm{N}$-terminally truncated $\mathrm{A} \beta 2-40$ / 42 peptides that display increased aggregation compared to non-truncated $A \beta$ peptides. This catalytic activity of meprin $\beta$ is differentially affected by mutated forms of
APP and in contrast to wt APP, meprin $\beta$ is not able to cleave APPswe at position 672 and does not generate Nterminally truncated forms of $A \beta$ from this APP mutant.

\section{Results}

\section{A knock-out of meprin $\beta$ leads to increased sAPPa secretion} in cortical neurons

We have previously shown that meprin $\beta$ is able to cleave APP and to generate $A \beta$ peptides in vitro $[20,21,24]$. We now wanted to elucidate the physiological role of meprin $\beta$ in APP processing in vivo. Therefore, we analyzed endogenous APP processing in the brains of meprin $\beta$ ko $(n=6)$ mice compared to age-matched wt animals $(n=6)$. Endogenous SAPP $\alpha$ and $\mathrm{SAPP} \beta$ were detected in the soluble fractions and full-length APP was detected in membrane fractions of brain lysates (Additional file 1). Levels of endogenous full-length APP remained identical (Fig. 2a), but the release of endogenous SAPP $\alpha$ was increased in meprin $\beta$ ko mice (Fig. 2a, b). This suggests that there might be more APP substrate for ADAMs in the absence of meprin $\beta$ and supports the involvement of endogenous meprin $\beta$ in APP processing in vivo (Additional file 2). The levels of sAPP $\beta$ were also slightly increased in meprin $\beta$ ko mice (Fig. 2a, c), but note, that the sAPP $\beta$ specific antibody (192wt, Fig. 1) recognizes only the neo C-terminus of sAPP $\beta$ after BACE-1 (or minor meprin $\beta$ ) cleavage between M671/D672 and is therefore not able to

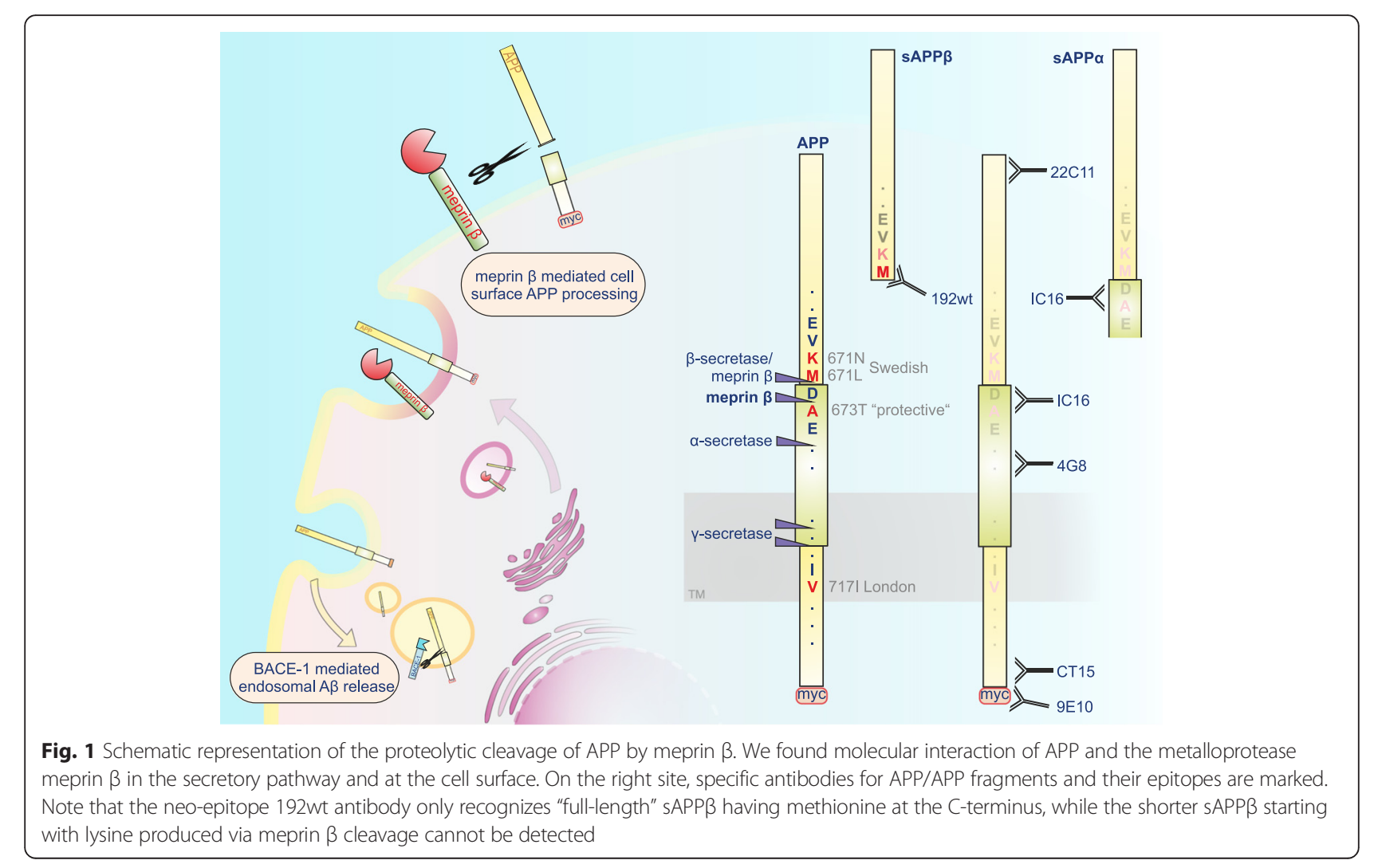


A

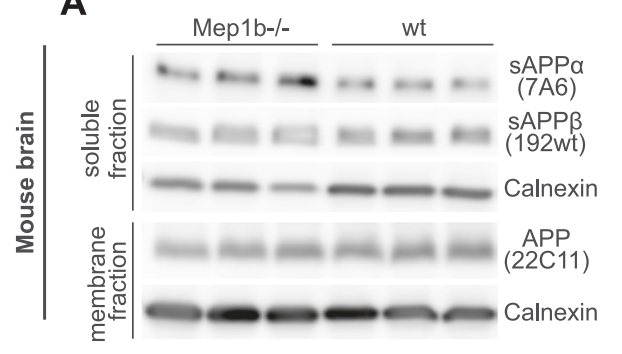

D

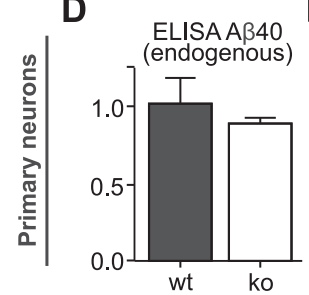

B

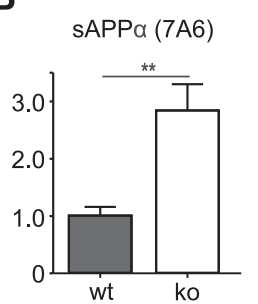

E

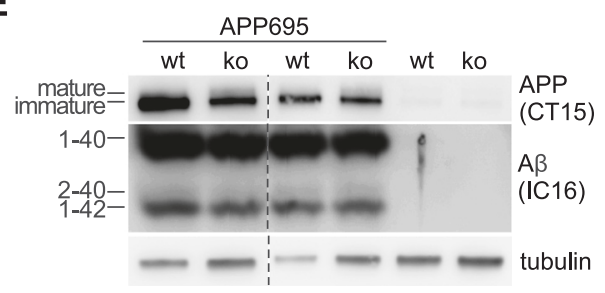

C

sAPP $(192 w t)$

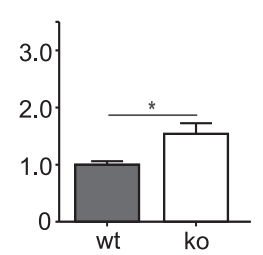

F

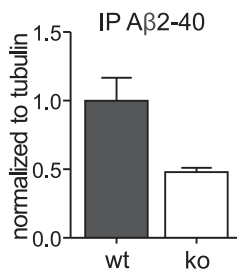

Fig. 2 Increased sAPPa levels in meprin $\beta$ ko mice. a-c Soluble and membrane fractions of brain lysates from meprin $\beta$ ko $\left(M e p 1 b^{-1-}\right.$ ) ( $\left.n=6\right)$ and wt $(n=6)$ mice were probed with antibodies specific for sAPPa (7A6), sAPP 3 (192wt) (Additional file 1), full-length APP (22C11) and actin or tubulin as loading controls (note that only representative $n=3$ for each is shown). $\mathbf{b}$ Note that endogenous sAPPa levels were increased in the absence of meprin $\beta$, indicating a changed APP processing profile in Mep $1 b^{-1-}$ compared to wt mice. d A 340 levels of supernatants of primary cortical neurons of wt $(n=3)$ and meprin ko mice $(n=6)$ were detected via Meso Scale ELISA using sulfo-tagged $4 \mathrm{G} 8$ antibody. Meprin $\beta$ ko mice showed approximately $13 \%$ less A 340 (normalized to total protein of lysates). e Urea gel of immunoprecipitated A (using IC16 antibody) of supernatants of primary cortical neurons of wt and meprin $\beta$ ko mice infected with a recombinant adenovirus expressing APP695. Lysates showed a decrease in mature APP for meprin $\beta$ ko (CT15 antibody). f Quantification of A $32-40$ levels (normalized to tubulin of lysates) of (e) showed a decrease of approximately $50 \%$ in meprin $\beta$ ko neurons $(n=2)$

detect the longer sAPP $\beta$ form generated by meprin $\beta$ cleavage between D672 and A673. Overall, these findings demonstrate that meprin $\beta$ affects endogenous APP processing in the mouse brain.

\section{Decrease of $A \beta 2-40$ and increase of mature APP in primary neurons of meprin $\beta$ knock-out mice}

Since we detected differences in SAPP $\alpha$ levels for wt versus meprin $\beta$ ko mice, we focused on total endogenous $A \beta$ in supernatants of primary cortical neurons. Via ELISA assay we could show that total A 340 levels showed a trend to decrease (by about $13 \%)$ in meprin $\beta$ ko neurons $(n=6)$ compared to controls $(n=6)$ (Fig. $2 \mathrm{~d})$; however due to the antibody specificity we were unable to detect any endogenous mouse A $32-40$. To circumvent this problem, we analysed $\mathrm{N}$-terminally truncated $\mathrm{A} \beta$ variants and precipitated $A \beta$ of supernatants of primary cortical neurons of the same mice infected with a recombinant adenovirus expressing APP695. We precipitated A $\beta$ from cell supernatants $48 \mathrm{~h}$ post infection with subsequent separation on $8 \mathrm{M}$ urea gels. We detected a decrease of $\mathrm{A} \beta 2-40$ levels in meprin $\beta$ ko neurons compared to wt of about $50 \%$ (Fig. 2e, f). Moreover, we observed an increase in levels of mature APP in neurons of meprin $\beta$ ko mice compared to wt controls (Fig. 2e), indicating processing of fully glycosylated APP after posttranslational modification by meprin $\beta$.

\section{BACE-1 activity is not increased by meprin $\beta$} preincubation

We have previously shown that generation of $A \beta 2-40$ by meprin $\beta$ in vitro is independent of BACE-1 [21]. However, since levels of $\mathrm{sAPP} \alpha$ are increased in meprin $\beta$ ko mice, we wanted to clarify if meprin $\beta$ is capable of regulating BACE-1 activity directly. Close to the proposed activation site in the propeptide of BACE-1 a patch of negatively charged amino acids is found. Meprin $\beta$ is known to prefer aspartate and glutamate residues around the cleavage site [24] and thus we performed a BACE-1 activity assay to test the potential role of meprin $\beta$ acting as an activator of BACE-1 by cleaving off the propeptide (Fig. 3). We incubated C-terminally truncated soluble recombinant proBACE-1 with active meprin $\beta$ and measured BACE-1 activity using a quenched fluorogenic peptide (mca-VNLDAE-dnp) comprising the sweAPP cleavage site. BACE-1 activity at acidic $\mathrm{pH}$ was not increased after meprin $\beta$ preincubation, indicating that there is no activity stimulating effect mediated by meprin $\beta$ (Fig. 3a, b). Meprin $\beta$ activity at $\mathrm{pH} 7.5$ was measured as control (Fig. 3c).

\section{Co-immunoprecipitation reveals interaction of APP and meprin $\beta$}

We have recently shown that APP is a substrate of the metalloprotease meprin $\beta$, even in BACE-1 knock-out cells [21]. However, in contrast to BACE-1 mediated 


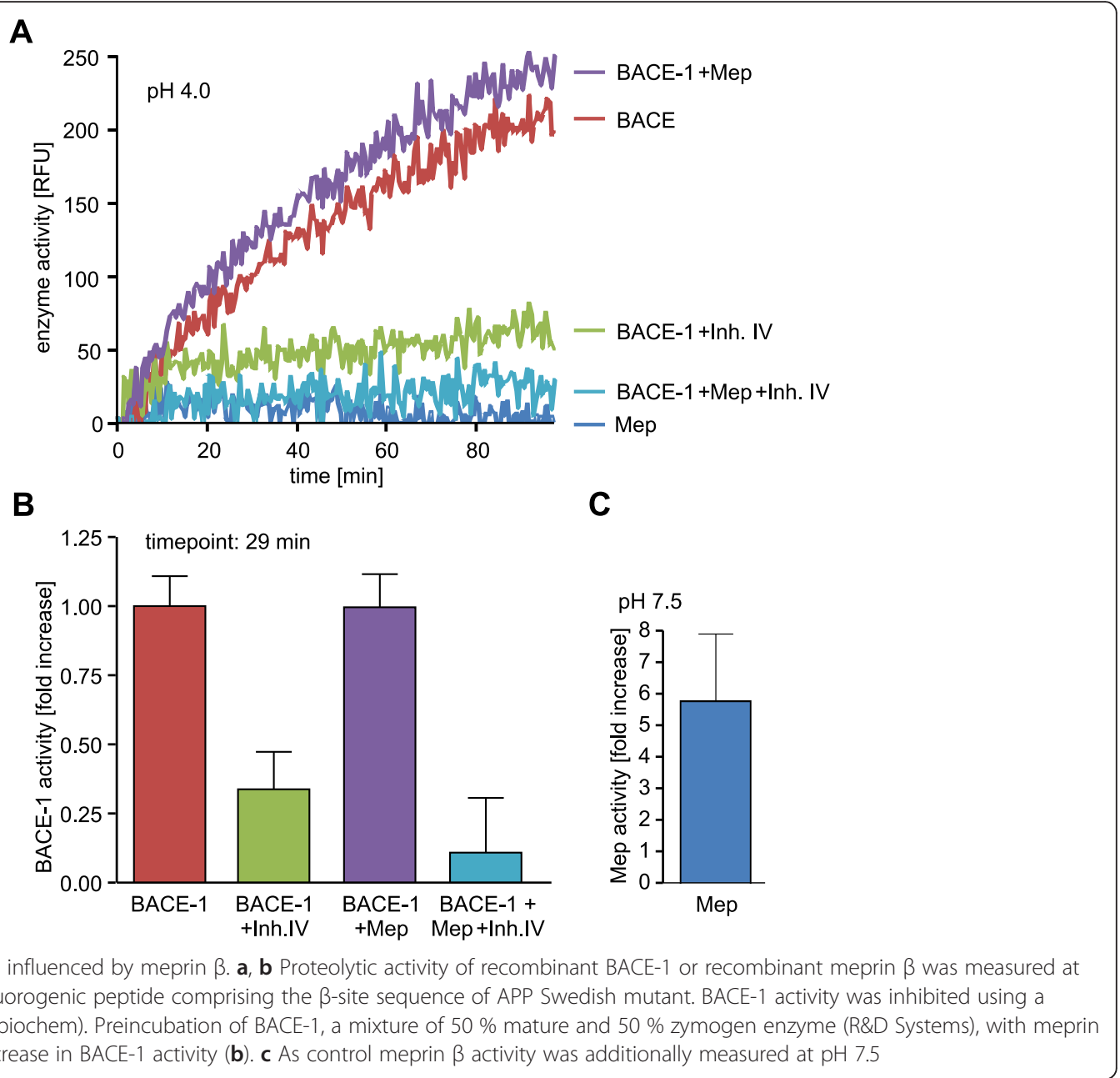

Fig. 3 BACE-1 activity is not influenced by meprin $\beta$. $\mathbf{a}$, b Proteolytic activity of recombinant BACE-1 or recombinant meprin $\beta$ was measured at pH 4.0 using a quenched fluorogenic peptide comprising the $\beta$-site sequence of APP Swedish mutant. BACE-1 activity was inhibited using a specific inhibitor (Inh IV, Calbiochem). Preincubation of BACE-1, a mixture of $50 \%$ mature and $50 \%$ zymogen enzyme (R\&D Systems), with meprin $\beta$ revealed no additional increase in BACE-1 activity (b). c As control meprin $\beta$ activity was additionally measured at pH 7.5

cleavage of APP, nothing was known about the cellular localization of meprin $\beta$ and APP interaction. To strengthen the involvement of meprin $\beta$ in APP processing, we first explored whether APP and meprin $\beta$ directly interact. We could show for the first time coimmunoprecipitation of myc-tagged APP and meprin $\beta$ with the 9E10 antibody (anti-myc) from lysates of HEK-293 $T$ cells transiently co-transfected with meprin $\beta$ and APP695myc (Fig. 4a). We could clearly observe an effect of meprin $\beta$ on APP processing in the lysate input control since levels of mature APP were decreased in co-transfected cells. Likewise, in a reverse experiment MEP1B antibody (anti-meprin $\beta$ ) co-precipitated transfected full length APP. Control experiments in which cells were single-transfected with APP ("L1") or meprin $\beta$ ("L2") with subsequent mixing of the cellular lysates (Mix) confirmed that immunoprecipitation with $9 \mathrm{E} 10$ or the meprin $\beta$ antibody only pulled either APP or meprin $\beta$ showing that the interaction of APP and meprin $\beta$ occurred only in the living cells and that APP and meprin $\beta$ specifically interacted only in co-transfected cells.

\section{APP and meprin $\beta$ co-localize in the late secretory pathway or at the cell membrane}

To further analyse the cellular localization of the APP/ meprin $\beta$ interaction and meprin $\beta$ enzymatic activity on APP processing, we used a well-established APP construct lacking the C-terminal motif NPxY (APP $\triangle \mathrm{NPxY}$ ), which is critical for proper endocytosis [2]. Using this construct allowed us to investigate APP processing prior to the endocytic compartment, hence prior to the BACE-1 mediated A $\beta$ generation. We performed a surface staining of MEF cells, transiently overexpressing meprin $\beta$ and APP $\triangle \mathrm{NPxY}$. To visualize only surface localized proteins we directly incubated the cells with anti-A $\beta$ IC16 antibody [25] and anti-meprin $\beta$ antibody after fixation and blocking without permeabilization to ensure that antibodies do not penetrate into the cell. The confocal images nicely show a co-localization of 


\section{A}

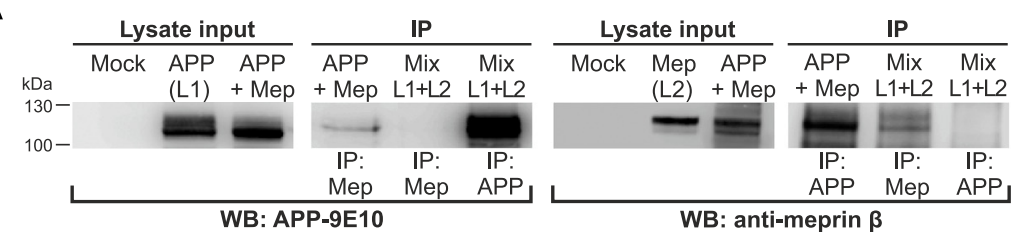

B
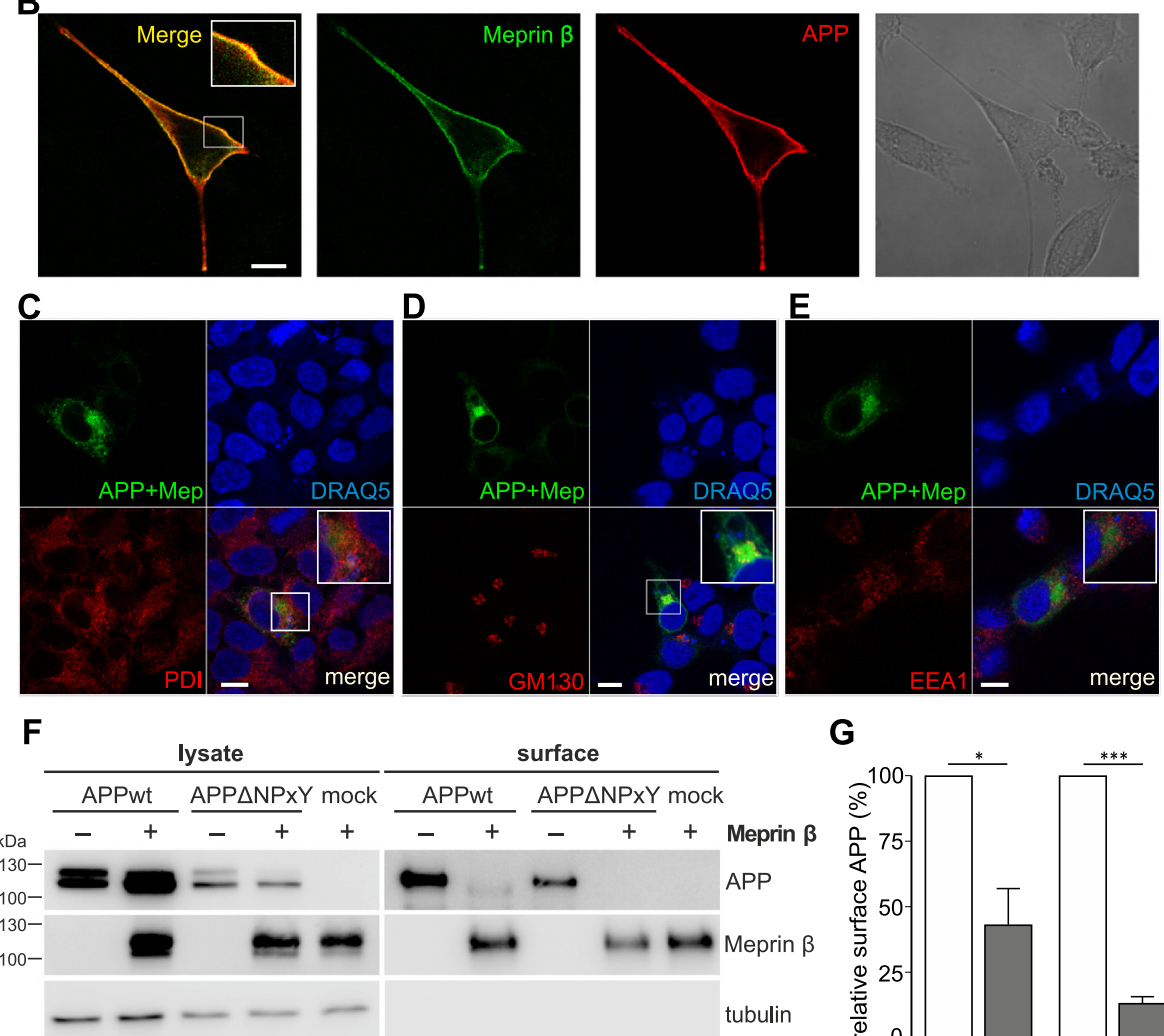

G

H
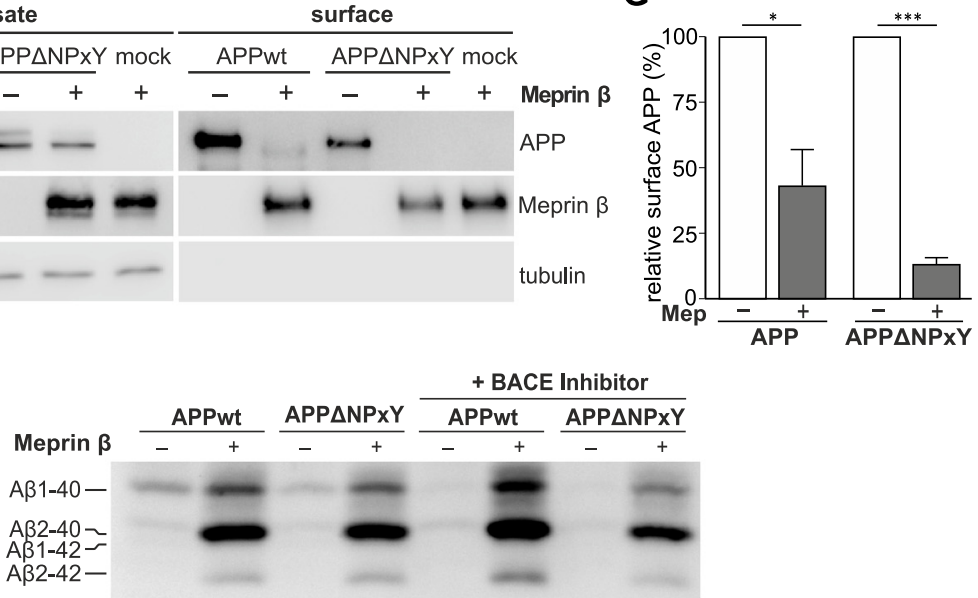

Fig. 4 (See legend on next page.) 
(See figure on previous page.)

Fig. 4 Cellular interaction between meprin $\beta$ and APP occurs prior to endocytosis. a APP695myc and meprin $\beta$ were overexpressed in HEK-293 T cells. Total lysates were immunoprecipitated with 9E10 (for APP) or anti-meprin $\beta$ antibody. Co-purified proteins were detected using antibodies as indicated (WB: 9E10 for APP and reciprocal WB: meprin $\beta$ ). $20 \mu \mathrm{g}$ of each lysate was used as transfection control (lysate input). As control, lysates of cells separately expressing either APP ("L1") or meprin $\beta$ ("L2"), were mixed post-lysis (lanes "Mix L1 + L2"). Co-purified proteins were immunoblotted as indicated. APP and meprin $\beta$ specifically interacted only in co-transfected cells, but not post-lysis. $\mathbf{b}$ MEF cells were transiently co-transfected with APP695 $\triangle N P x Y$ and meprin $\beta$. Surface staining was performed, using IC16 antibody for detection of APP and an anti-meprin $\beta$ antibody. Secondary antibodies Alexa-Fluor546 and Alexa-Fluor488 were used, respectively. The confocal image shows colocalization of APP (red) and meprin $\beta$ (green). Single channels are depicted aside. The right image shows the cell morphology as bright-field picture (Scale bar: $10 \mathrm{~nm})$. $(C, D, E)$ GFP fluorescence shows colocalizing APP and meprin $\beta$ (depicted in green) (Scale bar: $10 \mathrm{~nm}$ ). c Only little colocalization of APP and meprin $\beta$ can be found in the endoplasmic reticulum (PDI; depicted in red). $\mathbf{d}$ Colocalization was mostly found within the cis-golgi compartment (GM130; depicted in red). e Colocalization in early endosomes was hardly detectable (EEA1; depicted in red). f, g HEK-293 T cells were transiently co-transfected with APP695wt or APP $\triangle N P x Y$, and meprin $\beta$ or empty vector. Detection of proteins was carried out using specific antibodies. $\mathbf{f}$ $24 \mathrm{~h}$ post transfection, surface proteins were labeled using sulfo-NHS-LC-LC biotin and precipitated with NeutrAvidin agarose beads. $\mathbf{g}$ Quantification of biotinylated surface APP (graph shows mean \pm S.E. $(n=3)$; statistical significance: ${ }^{*}<0.05$, ${ }^{* * *} p<0.001$; $t$-test). $\mathbf{h}$ A $\beta$ variants of conditioned medium was immunoprecipitated using IC16-conjugated dynabeads and separated on $8 \mathrm{M}$ urea SDS-Page. Alternatively, cells were treated overnight with $100 \mathrm{nM}$ tripartite BACE-1 inhibitor [26]. Samples were run on one gel, but rearranged for better presentation. Shown is one representative of six independent experiments. Generation of A $\beta$ variants by meprin $\beta$ was preserved in endocytosis impaired APP $\triangle N P x Y$, indicating that cleavage occurred on the way to or at the cell surface

both proteins at the cell surface (Fig. 4b). As expected, our untransfected negative control and the controls of transfected cells that were only incubated with the corresponding secondary antibody, did not show any surface staining (data not shown).

To further highlight the colocalization of APP with meprin $\beta$, we co-transfected HEK cells with APP and meprin $\beta$ constructs that are tagged with a fragment of the green fluorescent protein (GFP) (APP-GFP11, only bearing barrel 11 of GFP; meprin $\beta$-GFP1-10, only bearing barrel 1-10). Neither the GFP11 fragment nor the GFP1-10 fragment alone showed any fluorescence. However, when both fragments are in close proximity, the function of an intact GFP is regained and it is emitting fluorescence. Thus, fluorescence in cells co-transfected with APP-GFP11 and meprin $\beta$-GFP1-10 indicates a colocalization of both proteins. Of note, colocalization was mostly found in the secretory pathway within the cis-golgi compartment (GM130 antibody) (Fig. 4d), there was lesser colocalization within the ER (PDI) (Fig. 4c), however hardly any in early endosomes (EEA1) (Fig. 4e). We further validated the specificity of this proposed colocalization using immunocytochemical stainings with organelle markers of fixed HEK cells tranfected with APP-GFP and meprin $\beta$-dsRed (Additional file 3).

To elucidate a potential APP processing by meprin $\beta$ at the cell surface, we transfected APP695wt or APP $\triangle N P x Y$ with or without meprin $\beta$ into HEK$293 \mathrm{~T}$ cells and performed a cell surface biotinylation assay (Fig. 4f). The mature form of APP is cleaved by meprin $\beta$ and is therefore reduced in cell lysates and at the cell surface. Surface APP695wt is almost completely cleaved and thus significantly reduced by $70 \%$ when meprin $\beta$ is also present at the cell surface (Fig. 4g). Surface APP $\triangle N P x Y$ is even stronger reduced by meprin $\beta$ by $85 \%$ when internalization is impaired. We further analyzed $A \beta$ variants derived from these cells using $8 \mathrm{M}$ urea SDS-Page. We could observe that an increased generation of $A \beta 1-40, A \beta 2$ 40 and $A \beta 2-42$ peptides by meprin $\beta$ is not dependent on internalization. Furthermore, to prove a direct involvement of meprin $\beta$ in $A \beta$ generation we inhibited BACE-1 activity using different BACE-1 inhibitors like a BACE-1 tripartite inhibitor (described in [26]) or BACE-1 IV inhibitor (data not shown). Inhibition of BACE- 1 activity did not alter the $A \beta$ pattern generated by meprin $\beta$, but decreased levels of $\mathrm{A} \beta 1-40$ in cells lacking meprin $\beta$ overexpression, which indicates the potency of the inhibitor (Fig. 4h). This suggests that meprin $\beta$ cleaves APP and generates $A \beta 2-40 / 42$ prior to the endocytic compartments as $\mathrm{APP} \triangle \mathrm{NPxY}$ proteins remain at the cell surface and seem to serve as more accessible substrates for meprin $\beta$.

\section{Meprin $\beta$ generated $A \beta 2-40$ promotes and seeds aggregation of $A \beta$ peptides}

As meprin $\beta$ generates $A \beta 2-40$ and $A \beta 2-42$ and since $\mathrm{N}$-terminally truncated $A \beta$ variants can be found in the CSF and senile plaques of $\mathrm{AD}$ patients [16], we were interested in the aggregation of the truncated and non-truncated (wt) A $\beta$ variants. Therefore, we compared the aggregation of truncated $A \beta 2-40$ and the non-truncated $A \beta 1-40$ variant. Aggregation was monitored by measuring the Thioflavin T (ThT) fluorescence upon binding to $A \beta$ aggregates (Fig. 5a). Both truncated $A \beta 2-40$ and non-truncated $A \beta 1-40$ variants showed characteristic sigmoidal aggregation curves. Interestingly, truncated $\mathrm{A} \beta 2-40$ peptide showed significantly faster aggregation as compared to nontruncated $A \beta 1-40$ peptide. The truncated $A \beta 2-40$ peptide had a shorter lag phase of about $\sim 12.5 \mathrm{~min}$ as 

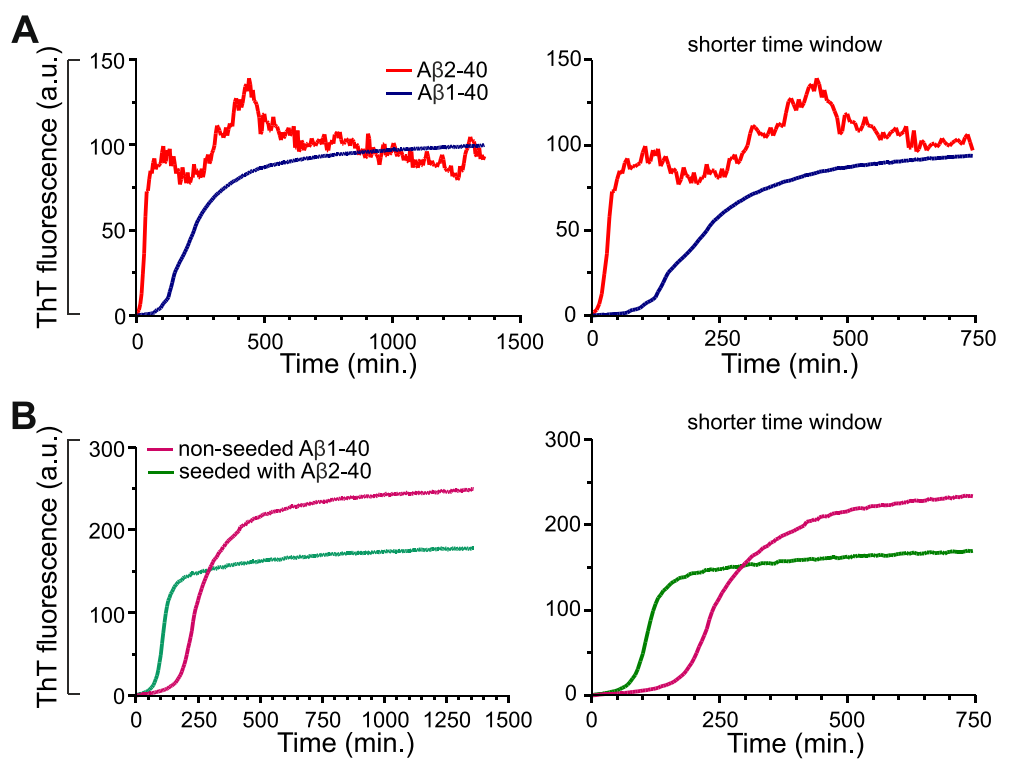

Fig. 5 A $2-40$ shows increased aggregation propensity and could seed the aggregation of non-truncated $A \beta$. Aggregation of synthetic $A \beta$ peptide (truncated $A \beta 2-40$ and non-truncated $A \beta 1-40$ ) variants were monitored by Thioflavin $T$ (ThT) fluorescence assay during incubation at 37 ${ }^{\circ} \mathrm{C}$ for $24 \mathrm{~h}$ (a). The aggregation assay was performed in $50 \mathrm{mM}$ sodium phosphate buffer and a final A $\beta$ concentration of $50 \mu \mathrm{M}$. The truncated A $32-40$ peptide demonstrate a shorter lag phase and rapid aggregation behavior as compared to non-truncated $A \beta 1-40$ variant. $\mathbf{b}$ Demonstration of the seeding capacity of $A \beta 2-40$ peptides. Aggregation of AB1-40 with and without preformed oligomeric nuclei of $A \beta 2-40$ was monitored by ThT fluorescence assay. Initial aggregate formation is accelerated by the addition of the A $32-40$ seeds, as indicated by the reduced lag phase. The graphs on the right-side in (a) and (b) display the same results with extended time scale to demonstrate the differences in the lag phase. The differences are statistically significant. For Unpaired $t$ test and $\mathrm{F}$ test, the $P$ value is $<0.0001$

compared to that of non-truncated $A \beta 1-40$ of $\sim 100$ min. In addition, truncated $A \beta 2-40$ also showed an increased elongation rate reaching a higher aggregation level than the $A \beta 1-40$ peptide. A decay in ThT fluorescence was observed with A $\beta 2-40$ peptide similar to the previously reported $\mathrm{N}$-terminal truncated A $34-x$ peptide, probably due to the masking of ThTbinding sites within higher order aggregates or clumps [27]. These data indicate that the aggregation of $\mathrm{N}$-terminally truncated $\mathrm{A} \beta 2-40$ peptide is significantly different from that of the non-truncated wt A $\beta 1-40$ peptide. In particular, the $A \beta 2-40$ species aggregate faster and reached a higher aggregation state than $\mathrm{A} \beta 1-40$ peptide.

We also investigated the seeding potency of the truncated $A \beta 2-40$ variant. In a nucleation-dependent aggregation assay, we studied the effect of truncated $A \beta$ variants on the aggregation of the non-truncated $A \beta$ variant. Preformed oligomeric nuclei of truncated A $\beta 2-40$ peptide significantly reduced the lag period of fibrillization (Fig. 5b). While A $\beta 1-40$ alone showed a characteristic lag phase ( $125 \mathrm{~min}$.), preformed oligomeric nuclei of truncated $A \beta 2-40$ strongly shortened the lag phase to $\sim 60 \mathrm{~min}$. Altogether, these data demonstrate that the truncated $A \beta 2-40$ aggregates rapidly, and also could efficiently seed the aggregation of non-truncated (wt) $\mathrm{A} \beta$ variants.

\section{The "protective" APP A673T mutation is less prone to cleavage by meprin $\beta$}

A recently described APP mutation in position 673 (A673T) has been shown to protect against $\mathrm{AD}$ as well as against cognitive decline in the elderly independently of $\mathrm{AD}$ [28-30]. This mutation is located adjacent to the $\beta$-secretase cleavage site in the $A \beta$ sequence at $p 2$ and reduces $A \beta$ generation by $40 \%$ in vitro. [28]. According to the findings reported above we speculated that this amino acid exchange (A673T) may also influence the affinity of meprin $\beta$ towards APP. To investigate the influence of this mutation on meprin $\beta$ cleavage of APP, we performed a cleavage assay using recombinant enzyme and synthetic peptides including the A673T mutation. HPLC and subsequent MALDI analysis revealed preferred cleavage of the wt over the A673T APP peptide by meprin $\beta$ (Fig. 6a, b; Additional file 4). Indeed, meprin $\beta$ prefers alanine over threonine in P1' position [24], which may explain reduced cleavage of APP A673T by meprin $\beta$.

To further clarify $A \beta$ generation by meprin $\beta$ from APP A673T in vitro, we compared $A \beta$ variants generated 

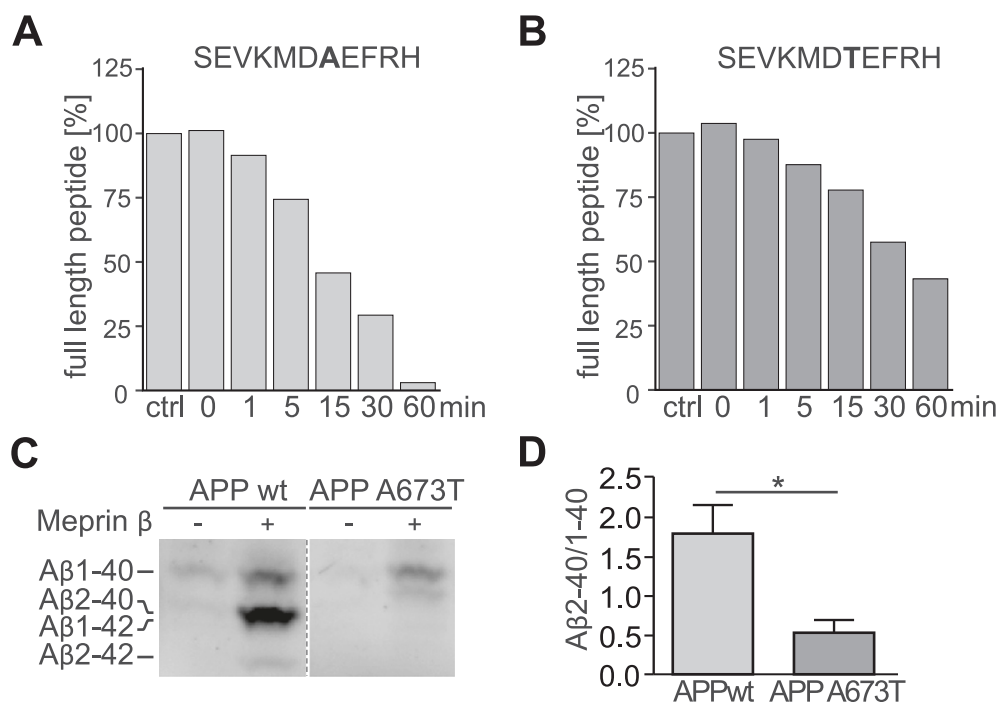

Fig. 6 The "protective" APP A673T mutation decreases cleavage by meprin $\beta$. a, b 15 nM recombinant meprin $\beta$ was incubated with synthetic APP peptides at $37{ }^{\circ} \mathrm{C}$. HPLC analysis showed that processing kinetics of APP A673T were decreased (b) compared to wt APP (a) (see also Additional file 4). c Supernatants of HEK-293 T cells, transiently transfected with APPwt or APP A673T mutant and co-transfected with meprin $\beta$ or empty vector were immunoprecipitated with anti-A 3 6E10-Dynabeads, subsequently separated on an $8 \mathrm{M}$ urea gel and probed with 6E10. The A $32-40$ band, visible in samples transfected with APPwt and meprin $\beta$, is slightly shifted in samples transfected with APP A673T and meprin $\beta$. All samples were run on one gel but rearranged for better presentation. $\mathbf{d}$ A significant decrease of the $A \beta 2-40 / 1-40$ ratio was observed in culture supernatants of cells co-transfected with APP A673T and meprin $\beta$ compared to cells co-transfected with APPwt and meprin $\beta$ (graph shows mean $\pm \operatorname{SEM}(n=5)$; statistical significance: ${ }^{*}, p=0.0317 ; t$-test $)$

of APPwt or APP A673T by meprin $\beta$ (Fig. 6c). In APP A673T transfected cells we observed no change in A $\beta 1-40$ levels compared to those of APPwt. Furthermore, we detected a distinct signal below the $A \beta 1-40$ band, which could not be attributed to one of the $A \beta$ marker peptides. However, we suggest that this band is also representing A $32-40$ (Additional file 5), but starting with a threonine at position two and shifted due to changes in hydrophobicity. Therefore, we compared the A $\beta 2-40 / 1-40$ ratio of APP695 wt and A673T mutant co-transfected with meprin $\beta$ (Fig. 6d). Our analysis revealed a significant decrease of $\sim 70 \%$ in the A $\beta 2-40 / 1-40$ ratio in the A673T mutant due to reduced $A \beta 2-40$ production (Fig. $6 \mathrm{~d}$ ).

\section{APPswe mutation affects meprin $\beta$ cleavage}

We have recently shown that meprin $\beta$ overexpression results in increased levels of A $\beta 2-40$. Therefore, we decided to use the $A \beta 2-40 / 1-40$ ratio as a measure for meprin $\beta$ activity. In contrast to BACE-1, meprin $\beta$ exhibits the same increased affinity for APPwt peptides and those carrying the Swedish mutation (K670N/M671L) in vitro [21]. However, here we demonstrate that generation of the $\mathrm{N}$ terminally truncated $A \beta 2-40 / 42$ variants by meprin $\beta$ from APP carrying the Swedish FAD mutation (APPswe) was almost completely abolished compared to APPwt controls (Fig. 7a, b). To analyse whether other FAD mutations may affect meprin $\beta$ activity in a similar fashion or whether only mutations localized closely to the $N$-terminus of the $A \beta$ sequence influence meprin $\beta$ cleavage specificity, we also investigated the FAD causing London APP mutation (APPlon, V717I). Using APPlon we observed that the ratio of $A \beta$ generation in meprin $\beta$ co-expressing cells is comparable to APPwt, indicating that changes close to the $\mathrm{N}$ terminal sequence of the $A \beta$ region may directly affect meprin $\beta$ cleavage specificity. Additionally, we tested the Swedish/London double mutation and could not detect a signal for A $\beta 2-40$ which can be therefore attributed to the APPswe mutation. To further support this, we employed data from a previously performed peptide cleavage assay [24], and analyzed with the help of a web-based tool [31], if the change of methionine (APPwt) to leucine (APPswe) alters the preference of meprin $\beta$ for certain amino acid residues around the cleavage site (Fig. 7c, d). Indeed, while aspartate in P1 position (nomenclature by Schechter \& Berger [32]) is highly preferred in APPwt, this residue is clearly disliked at this particular position when leucine is set in $\mathrm{P} 2$, explaining the loss of $A \beta 2-40 / 42$ generation by meprin $\beta$ in APPswe.

Overall, we could clearly show that the amino acid composition around the $\beta$-site in APP affect meprin $\beta$ cleavage preference. This is most striking for APPswe, which completely abolished A $\beta 2-40$ generation.

\section{Discussion}

The proteolytic cleavage of the amyloid precursor protein and the accumulation of $A \beta$ peptides in the brain 


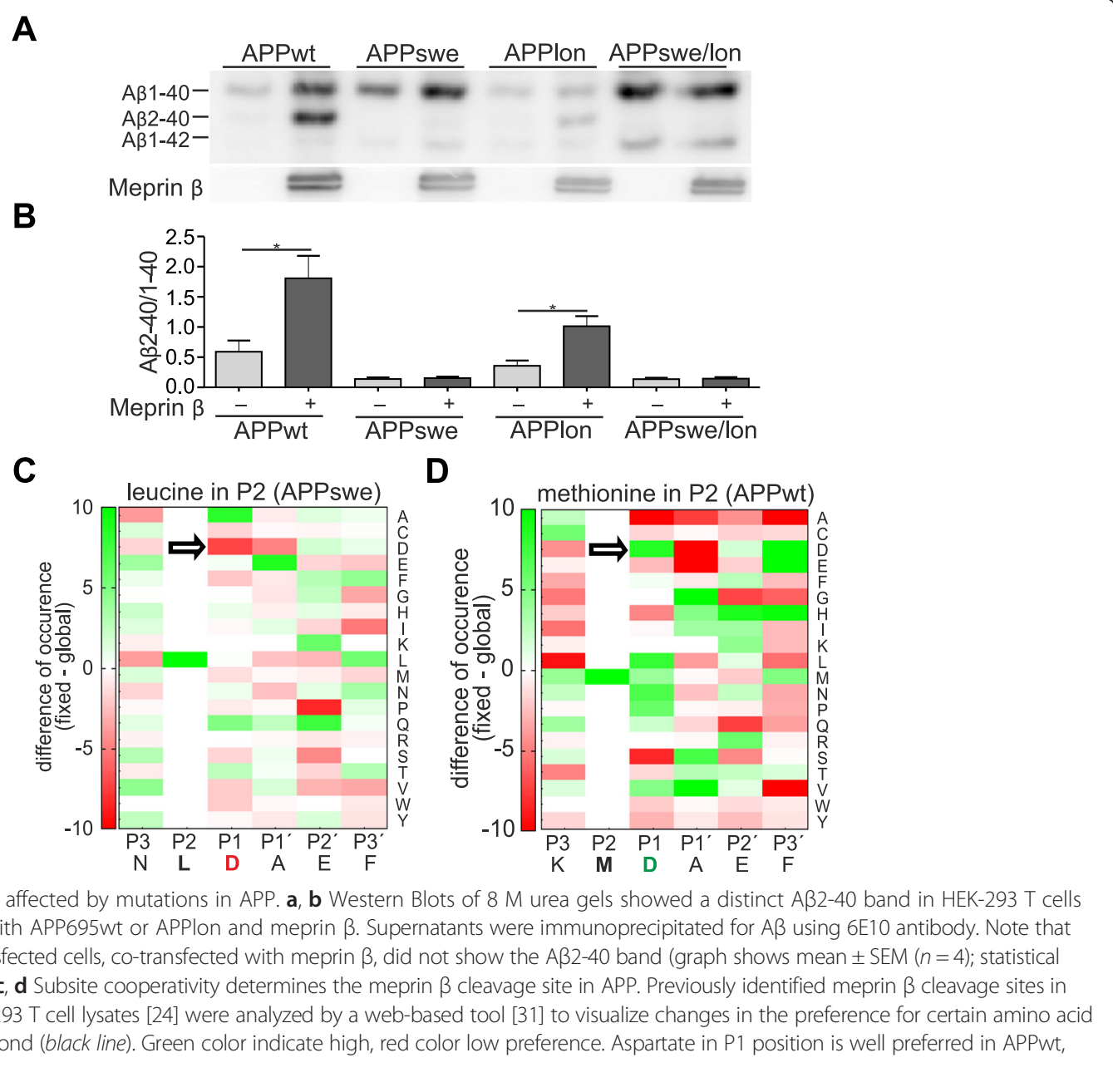

are key events in the pathogenesis of $\mathrm{AD}[10,33]$. It was shown that the deletion of BACE-1 in transgenic mice overexpressing APPswe abolishes $A \beta$ generation in the brain $[15,34-36]$ and rescues behavioral and electrophysiological deficits [34, 37]. However, several $\mathrm{N}$-terminally truncated $A \beta$ variants have also been described in the CSF and brains of $A D$ patients and cannot be attributed to BACE-1 activity [1, 16-19, 38-40]. This suggests that proteases other than BACE-1 may be involved in the generation of $\mathrm{N}$-terminally truncated $A \beta$ peptides in the brain. Since we could already show that the metalloprotease meprin $\beta$ generates $\mathrm{N}$-terminally truncated $A \beta$ peptides in vitro [21] we propose that it may be a candidate for this cleavage event. We already showed a different APP cleavage pattern in brains of meprin $\beta$ ko compared to wt mice, suggesting that meprin $\beta$ is involved in $\mathrm{N}$-terminal processing of endogenous APP in vivo [20]. In this study, we observed increased levels of endogenous SAPP $\alpha$ in meprin $\beta$ ko mice. sAPP $\alpha$ is generated through cleavage at the $\alpha$ secretase cleavage site within the $A \beta$ sequence by
ADAM10 [41-46]. A similar increase in sAPP $\alpha$ levels has been observed in BACE-1 ko mice or after treatment of mice with BACE-1 inhibitors [35, 47, 48]. We speculate that due to the absence of meprin $\beta$ more substrate is available for ADAM10 cleavage. Since the 192wt antibody does only recognize the shorter sAPP $\beta$ variant mainly produced by BACE-1cleavage, it does not reflect the total sAPP $\beta$ load (Fig. 1). Therefore, we can see an increase of this variant in meprin $\beta$ ko mice, since more substrate is available for BACE-1. Additionally, we detected a decrease of approximately $13 \%$ of endogenous $A \beta 40$ levels in meprin $\beta$ ko neurons compared to wt controls. To gain further insights into $A \beta$ production of endogenous meprin $\beta$ we infected primary meprin $\beta$ ko and wildtype control neurons with recombinant adenovirus expressing human APP695. These showed a decrease of approximately $50 \%$ of $A \beta 2-40$ levels compared to wt neurons. The remaining $A \beta 2-40$, which is also present in the ko, may be explained by other proteolytic events like $\mathrm{N}$-terminal truncation of the full-length $\mathrm{A} \beta$ originally generated by BACE-1, through aminopeptidases like APA 
[49]. We further wanted to elucidate whether there are other possible explanations for an increase of $\beta$-site cleavage in meprin $\beta$ wt versus ko mice, like an activation of BACE1 via meprin $\beta$. The propeptide of BACE-1 is cleaved off by furin or other proprotein convertases within the secretory pathway [50]. Interestingly, Creemers and colleagues showed that there is $\beta$-secretase activity towards APP which is not influenced by the presence of the propeptide. However, to exclude a potential role of meprin $\beta$ as BACE-1 cleaving and thus activating enzyme, we performed an activity assay. Our results illustrate that meprin $\beta$ has no effect on BACE-1 activity under $\mathrm{pH}$ conditions of active BACE-1.

As the interaction of BACE1 with APP at the cell surface and in early endosomes has been demonstrated [51,52], we were therefore interested whether we could detect a direct interaction of the metalloprotease meprin $\beta$ and its substrate APP. To further elucidate in which cellular compartment meprin $\beta$ mediated A $\beta$ generation occurs, we used an APP construct with impaired endocytosis due to a deletion of the tyrosine dependent sorting signal (NPxY motif; $\triangle \mathrm{NPxY})$ at the C-terminus [2, 53]. Since APP is endocytosed, most of the A $\beta 1-40 / 1-42$ generation and BACE-1 activity is found in endosomes due to its acidic $\mathrm{pH}$ optimum as an aspartyl protease [3-5]. Meprin $\beta$, however, belongs to the astacin family of zinc endopeptidases and is mainly active at or near the cell surface as a membrane-bound enzyme. Recently we could show that a hyperactive mutant of meprin $\beta$, which was exclusively localized at the secretory pathway and not secreted, resulted in enhanced APP shedding and A $\beta$ generation [54]. Additionally, rat meprin $\beta$ was shown to exhibit an acidic $\mathrm{pH}$ optimum with additional proteolytic activity at basic $\mathrm{pH}$ [55]. Therefore, it is possible that meprin $\beta$ cleaves APP in the late secretory pathway, at the cell surface or - like BACE-1 - in endosomes. To exclude the endosomal pathway for meprin $\beta$, we used APP $\triangle N P x Y$, which allows to normal post translational modification, maturation and transport to the cell surface. However, internalization and degradation of APP $\triangle N P x Y$ is impaired and thus BACE- 1 mediated $A \beta$ generation is strongly reduced $[2,56,57]$. We analyzed the processing of full-length APP and the generation of $\mathrm{N}$-terminally truncated $\mathrm{A} \beta$ in cells coexpressing APP $\triangle \mathrm{NPx} Y$ and meprin $\beta$. Mature surface APP almost completely vanished through cleavage of meprin $\beta$ and this effect was even greater when endocytosis of APP was impaired. In contrast to BACE-1, meprin $\beta$ was still able to cleave APP and to generate $\mathrm{N}$-terminally truncated $\mathrm{A} \beta$ peptides when internalization of APP is decreased. Thus, our results demonstrate a spatial segregation of APP cleavage by meprin $\beta$ from BACE-1 mediated APP cleavage. We hypothesize that still most of the initial APP processing of the amyloidogenic pathway occurs in the endosomal compartment by BACE-1, but that the $\mathrm{N}$ terminally truncated $A \beta 2-40$ and $A \beta 2-42$ variants are generated at or close to the cell surface by meprin $\beta$. Our immunofluorescence data using the split-GFP assay combined with antibody stainings against transfected proteins further support these results, since we could detect meprin $\beta$ and APP/APP $\triangle \mathrm{NPxY}$ in close proximity prior to internalization. Moreover, a recent study described that a hyperactive mutant of meprin $\beta$ led to massive shedding of APP already within the secretory pathway, again pointing to a potential interaction of the two proteins before endocytosis [54].

Some studies suggest that $\mathrm{N}$-terminally truncated $A \beta$ peptides may act as seeds and promote the aggregation of $\mathrm{A} \beta 1-40$ peptides with detrimental effects. So far, many studies have examined the characteristics of $\mathrm{A} \beta 3-\mathrm{x}$, which can be N-terminally cyclized to pyroglutamate $A \beta$ (pEA $33-x)[39,58-61], A \beta 4-x[1,27,62]$ and $A \beta 5-x[38,40,63]$. We have found meprin $\beta$ mediated generation of $A \beta 2-x$ and therefore analyzed its aggregation and nucleation propensities. Indeed, $A \beta 2-40$ has a high tendency to form aggregates compared to $A \beta 1-40$. Furthermore, we studied the effects of an $A \beta$ variant with high aggregation propensity over a variant with only low and could show that $A \beta 2-40$ peptide nucleates the aggregation of $A \beta 1-40$ in a dose-dependent manner. To our knowledge, this is the first study characterizing $A \beta 2-40$ showing that it has a high aggregation propensity and nucleates the aggregation of non-truncated $A \beta 1-40$ peptides in vitro.

Since several mutations within the APP sequence have been shown to have an impact on BACE-1 cleavage affinity on APP, we analyzed a recently described APP mutation A673T that has been shown to protect against $\mathrm{AD}$ as well as against cognitive decline in the elderly independent of $\mathrm{AD}$. The mutation lies at position two of $\mathrm{A} \beta(\mathrm{A} \beta-\mathrm{A} / \mathrm{T})$ and has been shown to reduce BACE-1 mediated $A \beta$ generation by $40 \%$ using synthetic peptides as substrates [28]. Moreover, a significantly decreased A $\beta$ production in human APP A673Toverexpressing primary neurons has been observed [30, 64]. Additionally, a decreased aggregation propensity of $\mathrm{A} \beta-\mathrm{A} / \mathrm{T}$ could be measured, which is showing the complexity of the protective effects of the substitution. Thus, we analyzed meprin $\beta$ mediated cleavage of APP A673T in cell culture and in a peptide cleavage assay and revealed a significant decrease of $\sim 70 \%$ in the A $\beta 2-40 / 1$ 40 ratio compared to wt APP. This is consistent with the data of our cleavage assay which focused on the cleavage preference of meprin $\beta$ by using recombinant enzyme and synthetic peptides including the mutation and 
analysis via HPLC and subsequent MALDI. Here, we detected the preference of alanine over threonine in $\mathrm{P} 1$ ' position [24]. Surprisingly, we observed that A $\beta 2-x$ variants were missing in cells overexpressing meprin $\beta$ and APP bearing the Swedish double mutation K670N/ M671L (APPswe) which is located in close vicinity of the $\beta$-secretase cleavage site. Here, we found a significantly reduced meprin $\beta$ mediated $A \beta 2-40 / 42$ generation. Although BACE-1 is clearly the most prominent enzyme responsible for the generation of $A \beta 1-40$ and $A \beta 1-42$ peptides from the APPwt or APPswe sequences, we propose, that meprin $\beta$ may be responsible for generating small amounts of N-terminal truncated $A \beta 2-40$ and A $32-42$ peptides almost exclusively from the APPwt sequences. This clearly shows a significant influence of amino acid substitutions around the $\beta$-secretase cleavage site for meprin $\beta$ mediated $A \beta$ generation. We suggest that the amino acid substitution close to the meprin $\beta$ cleavage site provides a mechanistic explanation for the differential generation of truncated $A \beta$ species from APPwt versus APPswe constructs.

\section{Conclusion}

Concluding, we observed increased endogenous sAPP $\alpha$ levels in the brains of meprin $\beta$ knock-out (ko) mice compared to wild-type controls. Moreover, we could show an interaction of APP and meprin $\beta$ by coimmunoprecipitation in overexpressing cells. Furthermore, we could demonstrate that, besides BACE-1, which is by far the most important secretase responsible for the generation of $A \beta$, meprin $\beta$ could be a subsidiary candidate protease in generating $\mathrm{N}$-terminally truncated, aggregation-prone $A \beta 2-x$ peptides that have been described in AD patients. We also observed that the $\beta$ secretase activity of meprin $\beta$ depends on the amino acid composition around the cleavage site in APP as demonstrated for the APPswe sequence and the AD protective mutant A673T. In particular, meprin $\beta$ was incapable of cleaving APPswe at position 672 and generating $\mathrm{N}$ terminally truncated $A \beta$ from this mutant substrate.

\section{Methods}

\section{Animals}

Mature congenic Mep1 $\beta^{-/-}$mice on a $\mathrm{C} 57 \mathrm{Bl} / 6$ background, as previously described [65], were maintained on a 12-h light-dark cycle, with food and water ad libitum. Control and $M e p 1 \beta^{-/-}$animals were anesthetized by sodium pentobarbital overdose and sacrificed by cervical dislocation. Entire brains were removed and subdissected into cerebellum, frontal cortex, temporal cortex, hippocampus and "the rest" of the brain prior to further analyses. All mice were kept under specific pathogen-free conditions.

\section{Mouse brain lysates}

Meprin $\beta$ ko $(n=6)$ and wt littermates $(n=6)$ were sacrificed by decapitation. Snap frozen hemispheres were homogenized in $1 \mathrm{ml}$ DEA buffer $(50 \mathrm{mM} \mathrm{NaCl}, 2 \mathrm{mM}$ EDTA, $0.2 \%$ diethylamine, protease inhibitors) and insoluble material was precipitated by centrifugation. DEA fraction was ultracentrifuged at $100.000 \times \mathrm{g}$ for $30 \mathrm{~min}$. The resulting supernatant was retained as the soluble fraction and neutralized by addition of $10 \% 0.5 \mathrm{M}$ Tris/ $\mathrm{HCl}, \mathrm{pH}$ 6.8. The DEA insoluble material was homogenized with $1 \%$ Triton-X lysis buffer and cleared by centrifugation [66]. Brain lysates were separated by SDSPAGE and subsequently probed using monoclonal antibody (mAb) 7A6 specific for sAPP $\alpha$, polyclonal antibody 192 specific for $\mathrm{SAPP} \beta, \mathrm{mAb} 22 \mathrm{C} 11$ recognizing the APP ectodomain, and actin for loading control [44]. For co-immunoprecipitation, brains were homogenized in lysis buffer (20 mM TrisHCl (pH 7.5), $150 \mathrm{mM} \mathrm{NaCl}$, $0.5 \%$ Triton X-100, protease inhibitors) [67].

\section{Enzyme Linked Immunosorbent Assay}

Samples were analysed by the A $\beta$ Triplex Immunoassay from Meso Scale Discovery using the sulfo-tagged 4G8 antibody for mouse $A \beta$ detection. $A \beta 40$ concentration was calculated using the MSD Discovery Workbench Software.

\section{Cortical cultures and infection}

Primary cortical neurons were obtained from prenatal (E15) mice. Dissociated neurons were seeded at a density of 63,000 cells $/ \mathrm{cm}^{2}$ on polyornithin (Sigma) precoated culture dishes and maintained in Neurobasal/B27 media (Gibco) supplemented with Glutamax (Gibco). Cells were infected with a recombinant adenovirus expressing human APP695 at a concentration of $100 \mathrm{pfu} /$ cell for $6 \mathrm{~h}$ in DIV1 as described [68].

\section{BACE-1 activity assay}

$1 \mu \mathrm{g}$ of C-terminally truncated recombinant proBACE1 (R\&D systems) was incubated with $15 \mathrm{nM}$ recombinant active meprin $\beta$ at $\mathrm{pH}$ 7.5. Afterwards, $\mathrm{pH}$ was changed to $\mathrm{pH} 4.0$ and BACE-1 activity was measured using a quenched fluorogenic peptide (mca-VNLDAE-dnp) comprising the sweAPP cleavage site. As control, BACE1 inhibitor IV (Calbiochem) was applied.

\section{Cell culture, transient transfection and cell lysis}

HEK-293 T cells were maintained and passaged in Dulbecco's Modified Eagle Serum (DMEM) supplemented with $5 \%$ fetal calf serum (FCS) and $0.5 \%$ sodium pyruvate in an incubator at $37{ }^{\circ} \mathrm{C}$ and $5 \% \mathrm{CO}_{2}$. Transient transfection of HEK-293 $\mathrm{T}$ cells was performed using calcium-phosphate or FuGENE ${ }^{\oplus D}$ (Promega). For all transfections the vectors pLHCX or pLBCX were used. 
$24 \mathrm{~h}$ post transfection, $293 \mathrm{~T}$ cells were lysed in NP-40 lysis buffer (500 mM Tris, pH 7.4, $150 \mathrm{mM} \mathrm{NaCl}, 5 \mathrm{mM}$ EDTA, 1 \% (v/v) Nonidet P-40, $0.02 \%$ (v/v) Sodium Azide), plus Complete Protease Inhibitor Cocktail (Roche) for $20 \mathrm{~min}$ at $4{ }^{\circ} \mathrm{C}$ on ice. Subsequently cell debris was pelleted by centrifugation at $20.000 \times \mathrm{x}$ for $20 \mathrm{~min}$ at $4{ }^{\circ} \mathrm{C}$ in a microcentrifuge. Protein content of cleared lysates was determined by BCA assay (Pierce Chemicals, Rockford, IL, USA).

\section{Co-immunoprecipitation of APP and meprin $\beta$}

HEK-293 T cells were transiently co-transfected with meprin $\beta$-pLBCX and APP695myc-pLHCX, or with either meprin $\beta$ or APP plus empty vector as control. $24 \mathrm{~h}$ post transfection, $293 \mathrm{~T}$ cells were lysed in NP-40 lysis buffer (500 mM Tris, pH 7.4, $150 \mathrm{mM} \mathrm{NaCl}, 5 \mathrm{mM}$ EDTA, $1 \%$ (v/v) Nonidet P-40, $0.02 \%$ (v/v) Sodium Azide), plus Complete Protease Inhibitor Cocktail (Roche) for $20 \mathrm{~min}$ at $4{ }^{\circ} \mathrm{C}$ on ice. $20 \mu \mathrm{g}$ of total cell lysates were used as input control. For co-immunoprecipitation, equal amounts of total lysates $(200 \mu \mathrm{g})$ were incubated over night with $30 \mu \mathrm{l}$ of protein $\mathrm{G}$ sepharose beads (50\% (v/v) slurry) (GE Healthcare), and either monoclonal 9E10 antibody for myc-tagged APP at 1:20 dilution, or polyclonal antimeprin $\beta$ antibody, MEP1B (R\&D Systems) at 1:100 dilution. Beads were collected by low speed centrifugation and washed three times with NP-40 lysis buffer. Bound proteins were eluted from sepharose beads with $30 \mu \mathrm{l} 2 \mathrm{x}$ SDS sample buffer at $95^{\circ} \mathrm{C}$.

\section{Split GFP cloning}

The plasmid pcDNA3.1-APP695 CT split GFP11 was used as template to subclone the APP695 CT split GFP11 construct into a pLHCX backbone with a $5^{\prime}$ HindIII and a $3^{\prime} \mathrm{ClaI}$ restriction site 31 . We used the plasmid pcDNA3.1-APP695 CT split GFP11 as a template to subclone meprin $\beta$ CT split GFP1 10 with a $5^{\prime} \mathrm{MluI}$ und $3{ }^{` C l a I}$ restriction site into $\mathrm{pLHCX}$.

\section{Immunofluorescence microscopy}

Murine embryonic fibroblasts (MEF) or HEK-293 T cells were seeded on cover slides precoated with polyornithin. For surface staining MEF cells were transiently co-transfected with meprin $\beta$-pLBCX and APP695 $\triangle$ NPxYmyc-pLHCX. For compartment staining HEK-293 T cells were transiently co-transfected with pLHCX-APP695 CT split GFP11 and pLHCX-meprin $\beta$ CT split GFP1-10. $24 \mathrm{~h}$ post transfection, cells were fixed with $4 \%$ PFA for $10 \mathrm{~min}$ at room temperature and, except MEF cells for the purpose of surface staining, permeabilized in $0.5 \%$ Triton $\mathrm{X}$ in PBS for $20 \mathrm{~min}$. For surface staining cells were washed three times with TBS before and after blocking in $4 \%$ BSA. Cells were incubated with IC16 antibody (1:300), recognizing residues $1-16$ of the human $A \beta$ sequence, and anti-meprin $\beta$ antibody (1:300), MEP1B (R\&D Systems), for $2 \mathrm{~h}$ at $37{ }^{\circ} \mathrm{C}$. For compartment staining cells were incubated with anti-PDI (abcam, 1:500), antiGM130 (BD Transduction Lab, 1:300) or anti EEA1 (Abcam, 1:300) for $2 \mathrm{~h}$ at $37^{\circ} \mathrm{C}$. Primary antibody was removed and cells were washed four times with TBS. Respective secondary Alexa-Fluor546 and Alexa-Fluor488 antibodies (Invitrogen) were applied in a 1:500 dilution in TBS for $1 \mathrm{~h}$ at room temperature in the dark. A secondary antibody control as well as a control with cells that were not transfected was performed. The coverslips were embedded in ProLong Gold antifade reagent (Invitrogen). Zstack images were acquired using a LSM710, AxioObserver confocal laser scanning microscope, Plan-Apochromat 63x/1.40 Oil DIC M27, using ZEN 2008 software (Carl Zeiss). A representative layer of $\mathrm{z}$-stack is presented in the results part.

\section{Immunoprecipitation of amyloid $\beta$}

Supernatants were normalized according to protein content of cell lysates $24 \mathrm{~h}$ post transfection. Immunoprecipitation (IP) with magnetic dynabeads M-280 was performed as described [69]. In brief, 5-fold concentrated IP detergent buffer (50 mM HEPES pH 7.4, $150 \mathrm{mM} \mathrm{NaCl}, 0.5 \%$ (v/v) Nonidet P-40 (NP40), $0.05 \%$ $(\mathrm{w} / \mathrm{v})$ SDS and protease inhibitor cocktail (Roche Complete) was mixed with supernatant. Magnetic dynabeads M-280 containing sheep-anti-mouse-IgG attached to their surface were precoated with $6 \mathrm{E} 10$ antibody (Covance) or IC16 antibody [25] for murine samples, both recognizing residues $1-16$ of the human $A \beta$ sequence, according to manufacturer's protocol and added to samples. After incubation for $15 \mathrm{~h}$ at $4{ }^{\circ} \mathrm{C}$ samples were washed three times with PBS, $0.1 \%$ BSA and once with $10 \mathrm{mM}$ Tris- $\mathrm{HCl}, \mathrm{pH}$ 7.5. Separation from beads was performed through boiling samples at $95{ }^{\circ} \mathrm{C}$ in $25 \mu \mathrm{l}$ sample buffer (0.36 M Bis-Tris, $0.16 \mathrm{M}$ Bicine, $1 \%(\mathrm{w} / \mathrm{v})$ SDS, $15 \%(w / v)$ sucrose and $0.0075 \%(w / v)$ bromophenol blue).

\section{$A \beta$ separation with $8 M$ Urea SDS-Gel and Western Blot}

Separation of immunoprecipitated $A \beta$ peptides was performed with $0.75 \mathrm{~mm}$ polyacrylamide $8 \mathrm{M}$ urea SDSgels as described [70]. To achieve a better separation of $\mathrm{A} \beta$ peptides varying in length of only one to few amino acids a final concentration of $0.3 \mathrm{M} \mathrm{H}_{2} \mathrm{SO}_{4}$ was used for separation gels. The peptides were transferred to an Immobilion-P PVDF membrane via semi-dry Western Blotting (Biorad) at $47 \mathrm{~mA} / \mathrm{gel}$ for $45 \mathrm{~min}$. Membranes were boiled for $3 \mathrm{~min}$ in PBS and afterwards blocked in $5 \%$ nonfat-dry milk in TBST for 30 min. 6E10 antibody (Covance, 1:1000 in TBST) or IC16 antibody was used for overnight immunostaining. After washing in TBST 
the membrane was incubated in secondary anti-mouse antibody (1:1000 in TBST) for $1 \mathrm{~h}$.

\section{Western Blotting, Quantification and statistical analysis}

Samples were eluted in SDS sample buffer and boiled at $95{ }^{\circ} \mathrm{C}$. Total lysates and immunoprecipitates were then separated on 4-12\% NuPage (Novex, Invitrogen) gradient gels and transferred onto nitrocellulose membranes or, for $A \beta$ separation, on Immobilion-P PVDF membranes after activation in methanol. After incubation with appropriate primary and secondary antibodies, immunoreactive bands were visualized using an ECL enhanced chemiluminescence system (Millipore). Western blots were quantified by densitometry using ImageJ 1.44. All graphs and statistical analyses were prepared using GraphPad Prism 4 software (GraphPad, La Jolla, CA, USA).

\section{Biotinylation}

HEK-293 T cells were either transiently co-transfected with human myc-tagged APP695wt-pLHCX or APP $\triangle$ NPxY-pLHCX and meprin $\beta$-pLBXC or with the empty vector alone and grown on $10 \mathrm{~cm}$ dishes to $90 \%$ confluency. Biotinylation was performed as previously described [71]. In brief, cell surface proteins were biotinylated with $0.5 \mathrm{mg} / \mathrm{ml}$ Sulfo-NHS-LC-LC-Biotin (Pierce) in ice-cold PBS at $4{ }^{\circ} \mathrm{C}$ for $40 \mathrm{~min}$. Cells were washed four times with ice-cold PBS containing $50 \mathrm{mM}$ $\mathrm{NH}_{4} \mathrm{Cl}$ to quench unconjugated biotin and lysed in NP40 buffer. Equal amounts of proteins were incubated with NeutrAvidin agarose resin (Pierce) at $4{ }^{\circ} \mathrm{C}$ overnight. Biotinylated proteins were recovered by boiling in $2 \times$ SDS sample buffer for $5 \mathrm{~min}$ and separated on 4$12 \%$ NuPage.

\section{Thioflavin T Binding Assay}

Synthetic human $A \beta 1-40$ and $A \beta 2-40$ peptides were procured from VCPBio Lab. Lyophilized peptides were solubilized in $10 \mathrm{mM} \mathrm{NaOH}$ to a final peptide concentration of $230 \mu \mathrm{M}$, sonicated for $5 \mathrm{~min}$ in water bath (Brandelin Sonopuls) and stored at $-80{ }^{\circ} \mathrm{C}$ until further use. Thioflavin $\mathrm{T}$ (ThT) binding assay was performed as described previously [72]. Briefly, $A \beta 1-40$ or $A \beta 2-40$ stock solution $(230 \mu \mathrm{M})$ was mixed with $50 \mathrm{mM}$ of sodium phosphate buffer (pH 7.4, $50 \mathrm{mM} \mathrm{NaCl}, 20 \mu \mathrm{M}$ ThT and $0.01 \%$ sodium azide) to final $A \beta$ concentration of $50 \mu \mathrm{M}$. Aggregation kinetic measurements were carried out using a Varian Cary Eclipse fluorescence spectrophotomer. Samples were incubated at $37{ }^{\circ} \mathrm{C}$ with stirring. The ThT fluorescence was measured every 5 min for $25 \mathrm{~h}$ using excitation and emission wavelengths of $446 \mathrm{~nm}$ and $482 \mathrm{~nm}$, with a slit width of $5 \mathrm{~nm}$ respectively. The samples were analyzed in duplicates in each measurement.
The values in the graph represents the means from 3 independent measurements $(n=6)$.

\section{In vitro seeding}

For seeding experiments, the previously aggregated $A \beta 2-$ 40 peptide solutions were sonicated for $5 \mathrm{~min}$ in a water bath and $5 \%$ (in volume and peptide concentration) aliquots of them were added to the fresh $A \beta 1-40$ sample just prior to incubation at the amyloidogenic condition. The seeded aggregation of $A \beta 1-40$ was then followed by ThT fluorescence measurement as described above. The samples were analyzed in duplicates. The values in graph represents the means from 2 independent measurements $(n=4)$.

\section{HPLC analysis}

Synthetic APP peptides (SEVKMDA ${ }_{376}$ EFRH or $\mathrm{SEVKMDT}_{376} \mathrm{EFRH}$ respectively) were incubated with 15 $\mathrm{nM}$ recombinant human meprin $\beta$ in $20 \mathrm{mM}$ HEPES for different time intervals at $37^{\circ} \mathrm{C}$. Recombinant meprin $\beta$ has been produced as previously described [73]. The reaction was stopped with $0.1 \% \mathrm{TFA} / \mathrm{H}_{2} \mathrm{O}$. Afterwards, reverse phase HPLC was performed using a gradient from $2 \%$ acetonitrile/ $0.1 \%$ TFA up to $60 \%$ acetonitrile/ $0.1 \%$ TFA in $38 \mathrm{~min}$. All peak fractions were collected and analyzed via MALDI MS.

\section{Additional files}

Additional file 1: Figure S1. Antibodies $192 \mathrm{wt}$ and $7 \mathrm{a} 6$ only detect SAPP in brain soluble fractions of wildtype mice. To test the specificity of the antibodies 7A6 and 192wt we compared brain soluble fractions of wildtype and APP ko mice. Here, we could show that by using the corresponding antibodies both SAPPa and SAPP $\beta$ are detectable in brain soluble fractions of wildtype, but are lacking in those of APP ko. Since APLP2 can also be detected in APP ko brain membrane fractions, we show that the knock-out is restricted to APP and does not involve other members of the APP family. (PDF $646 \mathrm{~kb}$ )

Additional file 2: Figure S2. ADAM10 protein levels are not altered in Mep $1 \mathrm{~b}-/-$ animals. To exclude that the lack of meprin $\beta$ has any effect on ADAM10 levels, which could affect SAPP levels, we analyzed lysates of whole brains from 16 week old Mep1b-/- and wt animals via SDS-PAGE. By using a C-terminal polyclonal ADAM10 antibody (pineda) we detected neither a difference on levels of mature ADAM10 nor on levels of the pro form proADAM10. Therefore, we suggest that, when meprin $\beta$ is lacking, the increase of sAPPa levels is indeed a result of higher substrate availability for ADAM10 which is independent on a lacking ADAM10/meprin $\beta$ interaction. (PDF $566 \mathrm{~kb}$ )

Additional file 3: Figure S3. APP and meprin $\beta$ colocalize in the secretory pathway and at the cell surface. HEK cells were co-transfected with APP-GFP and meprin $\beta$-dsRed. Both proteins predominantly colocalize in the cis-golgi compartment. Colocalization in early endosomes was hardly detectable. (PDF $890 \mathrm{~kb}$ )

Additional file 4: Figure S4. Meprin $\beta$ prefers cleavage of wt APP compared to APP A673T. $15 \mathrm{nM}$ recombinant meprin $\beta$ was incubated with synthetic APP peptides for different time intervals. HPLC analysis showed that processing kinetics of APP A376T (F-J) were decreased compared to wt APP (A-E). Occurring peaks with smaller retention times were identified as cleavage products by MALDI MS. Peak intensity has been measured at $214 \mathrm{~nm}$. (PDF $1715 \mathrm{~kb}$ ) 
Additional file 5: Figure S5. APP A673T mutation protects from meprin $\beta$ mediated cleavage. HEK-293 T cells were transiently transfected with APPwt or APP A673T mutant and co-transfected with the empty vector or meprin $\beta .24 \mathrm{~h}$ post transfection supernatants were immunoprecipitated using Dynabeads conjugated with a $6 \mathrm{E} 10$ anti-A $\beta$ antibody, subsequently separated on an $8 \mathrm{M}$ urea gel and probed with $1 \mathrm{E} 8$ anti-A $1-\mathrm{X} / 2-\mathrm{X}(\mathrm{A})$. The blot was reprobed with $6 \mathrm{E} 10$ anti-A $\beta$ antibody. All samples were run on one gel but rearranged for better presentation. (B) We could exclude a phosphorylation at the substituted threonine that causes a shift of AB2-40 by dephosphorylating with $\lambda$-phosphatase (New England Biolabs) after the last washing step of the immunoprecipitation. Samples were separated on an $8 \mathrm{M}$ urea gel and probed with $6 \mathrm{E} 10$ anti-AB antibody that showed no change with or without phosphatase treatment (C). (PDF $936 \mathrm{~kb}$ )

\section{Abbreviations}

AD: Alzheimer's Disease; APP: Amyloid precursor protein; APPswe: Swedish mutant APP; AB: Amyloid $\beta$; CTF: C-terminal fragment; FAD: Familial AD.

\section{Competing interests}

The authors declare that they have no competing interests.

\section{Authors' contributions}

$\mathrm{CS}$ and JB contributed equally to this work. CS, JB, SI, CBP and CP conceived the study. CS, JB, SI, RW, JP, HA, SK, JW, SFL, SW, MG, CBP and CP performed or designed experiments. SW, MG and CBP provided material. All authors read and approved the final manuscript.

\section{Acknowledgements}

We thank Dr. Ute Haußmann, Dr. Hans Klafki and Prof. Dr. Jens Wiltfang from the University of Duisburg-Essen for giving us technical support and their ongoing assistance. We thank Prof. Dr. Judith Bond for the generation of meprin $\beta$ knock-out mice. This work was supported in part by the DFG (Deutsche Forschungsgemeinschaft) PI379/6-1, PI379/5-2 (C.U.P.), CRC877 "Proteolysis as a Regulatory Event in Pathophysiology" (SFB 877/2 2014; A9 and A12), BE 4086/2-1 (C.B.P.), and the BMBF (KNDD; to CUP and SFL).

\section{Author details}

${ }^{1}$ Institute of Pathobiochemistry, University Medical Center of the Johannes Gutenberg University of Mainz, Duesbergweg 6, 55128 Mainz, Germany. ${ }^{2}$ Institute of Biochemistry, Unit for Degradomics of the Protease Web, Christian-Albrechts-University, Otto-Hahn-Platz 9, 24118 Kiel, Germany. ${ }^{3}$ Institute of Neuropathology, University Medical Center Hamburg-Eppendorf, 20246 Hamburg, Germany. ${ }^{4}$ Department of Neurology, Molecular Cell Biology, University of Bonn, 53127 Bonn, Germany. ${ }^{5}$ German Center for Neurodegenerative Diseases (DZNE) and Neuroproteomics, Klinikum rechts der Isar, Technische Universität München, 81675 Munich, Germany. ${ }^{6}$ Munich Cluster for Systems Neurology (SyNergy), Munich, Germany. ${ }^{7}$ Department of Neuropathology, Heinrich Heine University, 40225 Duesseldorf, Germany.

\section{Received: 31 July 2015 Accepted: 8 February 2016}

\section{Published online: 19 February 2016}

\section{References}

1. Vassar R, Kuhn PH, Haass C, Kennedy ME, Rajendran L, Wong PC, et al. Function, therapeutic potential and cell biology of BACE proteases: current status and future prospects. J Neurochem. 2014;130(1):4-28. doi:10.1111/jnc.12715.

2. Koo EH, Squazzo SL. Evidence that production and release of amyloid betaprotein involves the endocytic pathway. J Biol Chem. 1994;269(26):17386-9.

3. Vassar R, Bennett BD, Babu-Khan S, Kahn S, Mendiaz EA, Denis P, et al. Betasecretase cleavage of Alzheimer's amyloid precursor protein by the transmembrane aspartic protease BACE. Science. 1999;286(5440):735-41.

4. Golde TE, Estus S, Younkin LH, Selkoe DJ, Younkin SG. Processing of the amyloid protein precursor to potentially amyloidogenic derivatives. Science. 1992;255(5045):728-30.

5. Haass C, Schlossmacher MG, Hung AY, Vigo-Pelfrey C, Mellon A, Ostaszewski $\mathrm{BL}$, et al. Amyloid beta-peptide is produced by cultured cells during normal metabolism. Nature. 1992;359(6393):322-5. doi:10.1038/359322a0.

6. Sastre M, Steiner H, Fuchs $K$, Capell A, Multhaup G, Condron MM, et al. Presenilin-dependent gamma-secretase processing of beta-amyloid precursor protein at a site corresponding to the S3 cleavage of Notch. EMBO Rep. 2001;2(9):835-41. doi:10.1093/embo-reports/kve180.

7. Weidemann A, Eggert S, Reinhard FB, Vogel M, Paliga K, Baier G, et al. A novel epsilon-cleavage within the transmembrane domain of the Alzheimer amyloid precursor protein demonstrates homology with Notch processing. Biochemistry. 2002:41(8):2825-35.

8. Qi-Takahara Y, Morishima-Kawashima M, Tanimura Y, Dolios G, Hirotani N, Horikoshi Y, et al. Longer forms of amyloid beta protein: implications for the mechanism of intramembrane cleavage by gamma-secretase. J Neurosci. 2005;25(2):436-45. doi:10.1523/JNEUROSCI.1575-04.2005.

9. Takami M, Nagashima Y, Sano Y, Ishihara S, Morishima-Kawashima M, Funamoto $S$, et al. gamma-Secretase: successive tripeptide and tetrapeptide release from the transmembrane domain of beta-carboxyl terminal fragment. J Neurosci. 2009;29(41):13042-52. doi:10.1523/JNEUROSCI.2362-09. 2009.

10. Haass C, Selkoe DJ. Soluble protein oligomers in neurodegeneration: lessons from the Alzheimer's amyloid beta-peptide. Nat Rev Mol Cell Biol. 2007;8(2): 101-12. doi:10.1038/nrm2101.

11. Sinha S, Lieberburg I. Cellular mechanisms of beta-amyloid production and secretion. Proc Natl Acad Sci U S A. 1999;96(20):11049-53.

12. Yan $R$, Bienkowski MJ, Shuck ME, Miao H, Tory MC, Pauley AM, et al. Membrane-anchored aspartyl protease with Alzheimer's disease betasecretase activity. Nature. 1999;402(6761):533-7. doi:10.1038/990107.

13. Hussain I, Powell D, Howlett DR, Tew DG, Meek TD, Chapman C, et al. Identification of a novel aspartic protease (Asp 2) as beta-secretase. Mol Cell Neurosci. 1999;14(6):419-27. doi:10.1006/mcne.1999.0811.

14. Lin X, Koelsch G, Wu S, Downs D, Dashti A, Tang J. Human aspartic protease memapsin 2 cleaves the beta-secretase site of beta-amyloid precursor protein. Proc Natl Acad Sci U S A. 2000;97(4):1456-60.

15. Cai $H$, Wang $Y$, McCarthy $D$, Wen $H$, Borchelt DR, Price $D L$, et al. BACE1 is the major beta-secretase for generation of Abeta peptides by neurons. Nat Neurosci. 2001:4(3):233-4. doi:10.1038/85064.

16. Wiltfang J, Esselmann $H$, Cupers $P$, Neumann $M$, Kretzschmar $H$, Beyermann $M$, et al. Elevation of beta-amyloid peptide $2-42$ in sporadic and familial Alzheimer's disease and its generation in PS1 knockout cells. J Biol Chem. 2001:276(46):42645-57. doi:10.1074/jbc.M102790200.

17. Maler JM, Klafki HW, Paul S, Spitzer P, Groemer TW, Henkel AW, et al. Ureabased two-dimensional electrophoresis of beta-amyloid peptides in human plasma: evidence for novel Abeta species. Proteomics. 2007;7(20):3815-20. doi:10.1002/pmic.200700311.

18. Lewczuk P, Esselmann H, Otto M, Maler JM, Henkel AW, Henkel MK, et al. Neurochemical diagnosis of Alzheimer's dementia by CSF Abeta42, Abeta42/Abeta40 ratio and total tau. Neurobiol Aging. 2004;25(3):273-81. doi:10.1016/S0197-4580(03)00086-1.

19. Lewczuk P, Esselmann H, Bibl M, Paul S, Svitek J, Miertschischk J, et al. Electrophoretic separation of amyloid beta peptides in plasma. Electrophoresis. 2004;25(20):3336-43. doi:10.1002/elps.200406068.

20. Jefferson T, Causevic M, auf dem Keller U, Schilling O, Isbert S, Geyer R, et al. Metalloprotease meprin beta generates nontoxic $\mathrm{N}$-terminal amyloid precursor protein fragments in vivo. J Biol Chem. 2011;286(31):27741-50. doi:10.1074/jbc.M111.252718

21. Bien J, Jefferson T, Causevic M, Jumpertz T, Muenter L, Multhaup G, et al. The metalloprotease meprin beta generates amino terminal truncated Abeta-peptide species. J Biol Chem. 2012;287:33304-13. doi:10.1074/jbc. M112.395608.

22. Broder C, Becker-Pauly C. The metalloproteases meprin alpha and meprin beta: unique enzymes in inflammation, neurodegeneration, cancer and fibrosis. Biochem J. 2013;450(2):253-64. doi:10.1042/ BJ20121751.

23. Broder C, Arnold P, Vadon-Le Goff S, Konerding MA, Bahr K, Muller S, et al. Metalloproteases meprin alpha and meprin beta are C- and N-procollagen proteinases important for collagen assembly and tensile strength. Proc Natl Acad Sci U S A. 2013;110(35):14219-24. doi:10.1073/pnas.1305464110.

24. Becker-Pauly C, Barre O, Schilling O, Auf dem Keller U, Ohler A, Broder C et al. Proteomic analyses reveal an acidic prime side specificity for the astacin metalloprotease family reflected by physiological substrates. Mol Cell Proteomics. 2011;10(9):M111.009233. doi:10.1074/mcp.M111.009233.

25. Jager S, Leuchtenberger S, Martin A, Czirr E, Wesselowski J, Dieckmann M, et al. alpha-secretase mediated conversion of the amyloid precursor protein derived membrane stub C99 to C83 limits Abeta generation. J Neurochem. 2009;111(6):1369-82. doi:10.1111/j.1471-4159.2009.06420.x. 
26. Schieb $H$, Weidlich $S$, Schlechtingen $G$, Linning $P$, Jennings $G$, Gruner $M$, et al. Structural design, solid-phase synthesis and activity of membrane-anchored beta-secretase inhibitors on Abeta generation from wild-type and Swedish-mutant APP. Chemistry. 2010;16(48): 14412-23. doi:10.1002/chem.201002878.

27. Bouter $Y$, Dietrich K, Wittnam JL, Rezaei-Ghaleh N, Pillot T, Papot-Couturier S, et al. N-truncated amyloid beta (Abeta) 4-42 forms stable aggregates and induces acute and long-lasting behavioral deficits. Acta Neuropathol. 2013; 126(2):189-205. doi:10.1007/s00401-013-1129-2.

28. Jonsson T, Atwal JK, Steinberg S, Snaedal J, Jonsson PV, Bjornsson S, et al. A mutation in APP protects against Alzheimer's disease and age-related cognitive decline. Nature. 2012;488(7409):96-9. doi:10.1038/nature11283.

29. Kero M, Paetau A, Polvikoski T, Tanskanen $M$, Sulkava $R$, Jansson $L$ et al. Amyloid precursor protein (APP) A673T mutation in the elderly Finnish population. Neurobiol Aging. 2013;34(5):1518 e1-3. doi:10.1016/j. neurobiolaging.2012.09.017

30. Maloney JA, Bainbridge T, Gustafson A, Zhang S, Kyauk R, Steiner P, et al. Molecular mechanisms of Alzheimer disease protection by the A673T allele of amyloid precursor protein. J Biol Chem. 2014;289(45):30990-1000. doi:10. 1074/jbc.M114.589069.

31. Schilling O, Huesgen PF, Barre $O$, Auf dem Keller U, Overall CM. Characterization of the prime and non-prime active site specificities of proteases by proteome-derived peptide libraries and tandem mass spectrometry. Nat Protoc. 2011;6(1):111-20. doi:10.1038/nprot.2010.178.

32. Schechter I, Berger A. On the size of the active site in proteases. I. Papain. Biochem Biophys Res Commun. 1967;27(2):157-62.

33. Hardy J, Selkoe DJ. The amyloid hypothesis of Alzheimer's disease: progress and problems on the road to therapeutics. Science. 2002;297(5580):353-6. doi:10.1126/science.1072994.

34. Dominguez D, Tournoy J, Hartmann D, Huth T, Cryns K, Deforce S, et al. Phenotypic and biochemical analyses of BACE1- and BACE2-deficient mice. J Biol Chem. 2005;280(35):30797-806. doi:10.1074/jbc.M505249200.

35. Luo Y, Bolon B, Kahn S, Bennett BD, Babu-Khan S, Denis P, et al. Mice deficient in BACE1, the Alzheimer's beta-secretase, have normal phenotype and abolished beta-amyloid generation. Nat Neurosci. 2001;4(3):231-2 doi:10.1038/85059.

36. Roberds SL, Anderson J, Basi G, Bienkowski MJ, Branstetter DG, Chen KS, et al. BACE knockout mice are healthy despite lacking the primary betasecretase activity in brain: implications for Alzheimer's disease therapeutics. Hum Mol Genet. 2001;10(12):1317-24

37. Ohno M, Sametsky EA, Younkin LH, Oakley H, Younkin SG, Citron M, et al. BACE1 deficiency rescues memory deficits and cholinergic dysfunction in a mouse model of Alzheimer's disease. Neuron. 2004;41(1):27-33.

38. Takeda K, Araki W, Akiyama H, Tabira T. Amino-truncated amyloid betapeptide (Abeta5-40/42) produced from caspase-cleaved amyloid precursor protein is deposited in Alzheimer's disease brain. FASEB J. 2004;18(14):17557. doi:10.1096/fj.03-1070fje.

39. Guntert A, Dobeli H, Bohrmann B. High sensitivity analysis of amyloid-beta peptide composition in amyloid deposits from human and PS2APP mouse brain. Neuroscience. 2006;143(2):461-75. doi:10.1016/j.neuroscience.2006.08. 027.

40. Murayama KS, Kametani F, Tabira T, Araki W. A novel monoclonal antibody specific for the amino-truncated beta-amyloid Abeta5-40/42 produced from caspase-cleaved amyloid precursor protein. J Neurosci Methods. 2007;161(2): 244-9. doi:10.1016/j.jneumeth.2006.11.010.

41. Lammich S, Kojro E, Postina R, Gilbert S, Pfeiffer R, Jasionowski M, et al. Constitutive and regulated alpha-secretase cleavage of Alzheimer's amyloid precursor protein by a disintegrin metalloprotease. Proc Natl Acad Sci U S A. 1999:96(7):3922-7.

42. Postina R, Schroeder A, Dewachter I, Bohl J, Schmitt U, Kojro E, et al. A disintegrin-metalloproteinase prevents amyloid plaque formation and hippocampal defects in an Alzheimer disease mouse model. J Clin Invest. 2004;113(10):1456-64. doi:10.1172/JCI20864.

43. Jorissen E, Prox J, Bernreuther C, Weber S, Schwanbeck R, Serneels L, et al. The disintegrin/metalloproteinase ADAM10 is essential for the establishment of the brain cortex. J Neurosci. 2010;30(14):4833-44. doi:10. 1523/JNEUROSCI.5221-09.2010.

44. Kuhn PH, Wang H, Dislich B, Colombo A, Zeitschel U, Ellwart JW, et al. ADAM10 is the physiologically relevant, constitutive alpha-secretase of the amyloid precursor protein in primary neurons. EMBO J. 2010;29(17):3020-32 doi:10.1038/emboj.2010.167.
45. Sisodia SS, Koo EH, Beyreuther K, Unterbeck A, Price DL. Evidence that betaamyloid protein in Alzheimer's disease is not derived by normal processing. Science. 1990;248(4954):492-5.

46. Esch FS, Keim PS, Beattie EC, Blacher RW, Culwell AR, Oltersdorf T, et al. Cleavage of amyloid beta peptide during constitutive processing of its precursor. Science. 1990;248(4959):1122-4.

47. Nishitomi K, Sakaguchi G, Horikoshi Y, Gray AJ, Maeda M, Hirata-Fukae C, et al. BACE1 inhibition reduces endogenous Abeta and alters APP processing in wild-type mice. J Neurochem. 2006;99(6):1555-63. doi:10.1111/j.14714159.2006.04178.x

48. Hussain I, Hawkins J, Harrison D, Hille C, Wayne G, Cutler L, et al. Oral administration of a potent and selective non-peptidic BACE-1 inhibitor decreases beta-cleavage of amyloid precursor protein and amyloid-beta production in vivo. J Neurochem. 2007;100(3):802-9. doi:10.1111/j.14714159.2006.04260.x.

49. Sevalle J, Amoyel A, Robert P, Fournie-Zaluski MC, Roques B, Checler F. Aminopeptidase A contributes to the $\mathrm{N}$-terminal truncation of amyloid beta-peptide. J Neurochem. 2009;109(1):248-56. doi:10.1111/j.1471-4159. 2009.05950.x.

50. Creemers JW, Ines Dominguez D, Plets E, Serneels L, Taylor NA, Multhaup G, et al. Processing of beta-secretase by furin and other members of the proprotein convertase family. J Biol Chem. 2001;276(6):4211-7. doi:10.1074/ jbc.M006947200.

51. Kinoshita A, Fukumoto H, Shah T, Whelan CM, Irizarry MC, Hyman BT. Demonstration by FRET of BACE interaction with the amyloid precursor protein at the cell surface and in early endosomes. J Cell Sci. 2003;116(Pt 16):3339-46. doi:10.1242/jcs.00643.

52. Das U, Scott DA, Ganguly A, Koo EH, Tang Y, Roy S. Activity-induced convergence of APP and BACE-1 in acidic microdomains via an endocytosis-dependent pathway. Neuron. 2013;79(3):447-60. doi:10.1016/j. neuron.2013.05.035

53. Bonifacino JS, Traub LM. Signals for sorting of transmembrane proteins to endosomes and lysosomes. Annu Rev Biochem. 2003;72:395-447. doi:10. 1146/annurev.biochem.72.121801.161800.

54. Arnold P, Schmidt F, Prox J, Zunke F, Pietrzik C, Lucius R et al. Calcium negatively regulates meprin beta activity and attenuates substrate cleavage. FASEB J. 2015;29:000-. doi:10.1096/fj.15-272310.

55. Bertenshaw GP, Villa JP, Hengst JA, Bond JS. Probing the active sites and mechanisms of rat metalloproteases meprin A and B. Biol Chem. 2002; 383(7-8):1175-83. doi:10.1515/BC.2002.129.

56. Perez RG, Soriano S, Hayes JD, Ostaszewski B, Xia W, Selkoe DJ, et al. Mutagenesis identifies new signals for beta-amyloid precursor protein endocytosis, turnover, and the generation of secreted fragments, including Abeta42. J Biol Chem. 1999:274(27):18851-6.

57. Lai A, Sisodia SS, Trowbridge IS. Characterization of sorting signals in the beta-amyloid precursor protein cytoplasmic domain. J Biol Chem. 1995; 270(8):3565-73.

58. Mori H, Takio K, Ogawara M, Selkoe DJ. Mass spectrometry of purified amyloid beta protein in Alzheimer's disease. J Biol Chem. 1992;267(24):17082-6.

59. Harigaya Y, Saido TC, Eckman CB, Prada CM, Shoji M, Younkin SG. Amyloid beta protein starting pyroglutamate at position 3 is a major component of the amyloid deposits in the Alzheimer's disease brain. Biochem Biophys Res Commun. 2000:276(2):422-7. doi:10.1006/bbrc.2000.3490.

60. Wittnam $J$, Portelius E, Zetterberg H, Gustavsson MK, Schilling S, Koch B, et al. Pyroglutamate amyloid beta (Abeta) aggravates behavioral deficits in transgenic amyloid mouse model for Alzheimer disease. J Biol Chem. 2012; 287(11):8154-62. doi:10.1074/jbc.M111.308601.

61. Gunn AP, Masters CL, Cherny RA. Pyroglutamate-Abeta: role in the natural history of Alzheimer's disease. Int J Biochem Cell Biol. 2010;42(12):1915-8. doi:10.1016/j.biocel.2010.08.015

62. Masters $C L$, Simms G, Weinman NA, Multhaup G, McDonald BL, Beyreuther K. Amyloid plaque core protein in Alzheimer disease and Down syndrome. Proc Natl Acad Sci U S A. 1985;82(12):4245-9.

63. Portelius E, Olsson M, Brinkmalm G, Ruetschi U, Mattsson N, Andreasson U, et al. Mass spectrometric characterization of amyloid-beta species in the 7PA2 cell model of Alzheimer's disease. J Alzheimers Dis. 2013;33(1):85-93. doi:10.3233/JAD-2012-120994.

64. Benilova I, Gallardo R, Ungureanu AA, Castillo Cano V, Snellinx A, Ramakers $M$, et al. The Alzheimer disease protective mutation A2T modulates kinetic and thermodynamic properties of amyloid-beta (abeta) aggregation. J Biol Chem. 2014;289(45):30977-89. doi:10.1074/jbc.M114.599027. 
65. Yura RE, Bradley SG, Ramesh G, Reeves WB, Bond JS. Meprin A metalloproteases enhance renal damage and bladder inflammation after LPS challenge. Am J Physiol Renal Physiol. 2009;296(1):F135-44. doi:10.1152/ ajprenal.90524.2008.

66. Kuhn PH, Koroniak K, Hogl S, Colombo A, Zeitschel U, Willem M, et al. Secretome protein enrichment identifies physiological BACE1 protease substrates in neurons. EMBO J. 2012;31(14):3157-68. doi:10.1038/emboj. 2012.173.

67. Xiang YY, Dong H, Yang BB, Macdonald JF, Lu WY. Interaction of acetylcholinesterase with neurexin-1 beta regulates glutamatergic synaptic stability in hippocampal neurons. Mol Brain. 2014;7:15. doi:10.1186/17566606-7-15.

68. Weggen S, Eriksen JL, Das P, Sagi SA, Wang R, Pietrzik CU, et al. A subset of NSAIDs lower amyloidogenic Abeta42 independently of cyclooxygenase activity. Nature. 2001:414(6860):212-6. doi:10.1038/35102591.

69. Wiltfang J, Esselmann H, Bibl M, Smirnov A, Otto M, Paul S, et al. Highly conserved and disease-specific patterns of carboxyterminally truncated Abeta peptides 1-37/38/39 in addition to 1-40/42 in Alzheimer's disease and in patients with chronic neuroinflammation. J Neurochem. 2002:81(3):481-96.

70. Klafki HW, Wiltfang J, Staufenbiel M. Electrophoretic separation of betaA4 peptides (1-40) and (1-42). Anal Biochem. 1996;237(1):24-9. doi:10.1006/ abio.1996.0195.

71. Wagner T, Dieckmann M, Jaeger S, Weggen S, Pietrzik CU. Stx5 is a novel interactor of VLDL-R to affect its intracellular trafficking and processing. Exp Cell Res. 2013;319(13):1956-72. doi:10.1016/.jyexcr.2013.05.010.

72. Kumar S, Rezaei-Ghaleh N, Terwel D, Thal DR, Richard M, Hoch M, et al. Extracellular phosphorylation of the amyloid beta-peptide promotes formation of toxic aggregates during the pathogenesis of Alzheimer's disease. EMBO J. 2011;30(11):2255-65. doi:10.1038/emboj.2011.138

73. Becker C, Kruse MN, Slotty KA, Kohler D, Harris JR, Rosmann S, et al. Differences in the activation mechanism between the alpha and beta subunits of human meprin. Biol Chem. 2003;384(5):825-31. doi:10.1515/ BC.2003.092.

\section{Submit your next manuscript to BioMed Central and we will help you at every step:}

- We accept pre-submission inquiries

- Our selector tool helps you to find the most relevant journal

- We provide round the clock customer support

- Convenient online submission

- Thorough peer review

- Inclusion in PubMed and all major indexing services

- Maximum visibility for your research

Submit your manuscript at www.biomedcentral.com/submit 